\title{
Dinosaurs (Reptilia, Archosauria) at Museo de La Plata, Argentina: annotated catalogue of the type material and Antarctic specimens
}

\author{
Alejandro Otero and Marcelo Reguero
}

\begin{abstract}
A commented-illustrated catalogue of non-avian dinosaurs housed at Museo de La Plata, Argentina is presented. This represents the first commented catalogue of the La Plata Museum dinosaurs to be published. This includes the type material as well as Antarctic specimens. The arrangement of the material was made in a phylogenetic fashion, including systematic rank, type material, referred specimens, geographic and stratigraphic location, and comments/remarks, when necessary. A total of 13 type specimens of non-avian dinosaurs are housed at the collection of Museo de La Plata, including eight sauropods, one theropod, one ornithischian, and three ichnotaxa. There are four Antarctic specimens, one of which is a holotype, whereas other corresponds to the first sauropod dinosaur registered for that continent.
\end{abstract}

Alejandro Otero. División Paleontología de Vertebrados, Museo de La Plata. Paseo del Bosque s/n (1900), La Plata, Argentina. alexandros.otero@gmail.com

Marcelo Reguero. División Paleontología de Vertebrados, Museo de La Plata. Paseo del Bosque s/n (1900), La Plata, Argentina. regui@fcnym.unlp.edu.ar

Keywords: Saurischia; Ornithischia; Holotype; Lectotype; Patagonia; Antarctica

\section{INTRODUCTION}

The Museo de La Plata (MLP), constructed in 1884 , is one of the oldest museums of natural history of South America. The collection of the División Paleontología de Vertebrados (DPV) was created in 1877 when the museum's future Director, Dr. Francisco Pascasio Moreno, donated 15,000 pieces. In addition to those original bones, numerous dinosaur materials from Argentina and Antarctica (Figure 1) have been collected and accessioned during more than a century and housed at the DPV collection, reaching more than 600 individual bones. These include 13 type material and otherwise important dinosaur specimens, which include ornithischians (e.g., ornithopods, ankylosaurs), saurischians (e.g., theropods, sauropodomorphs), as well as three ichnospecies included (see Table 1 for a summary of the taxa presented).

Many fossil vertebrate catalogues of the Museo de La Plata were previously published, mostly devoted to mammals (Mercerat, 1891,

PE Article Number: 16.1.3T

Copyright: Palaeontological Association March 2013

Submission: 14 September 2012. Acceptance: 6 March 2013

Otero, Alejandro and Reguero, Marcelo. 2013. Dinosaurs (Reptilia, Archosauria) at Museo de La Plata, Argentina: annotated catalogue of the type material and Antarctic specimens, Palaeontologia Electronica Vol. 16, Issue 1; 3T; 24p; palaeo-electronica.org/content/2013-technical/410-museo-de-la-plata-catalogue 


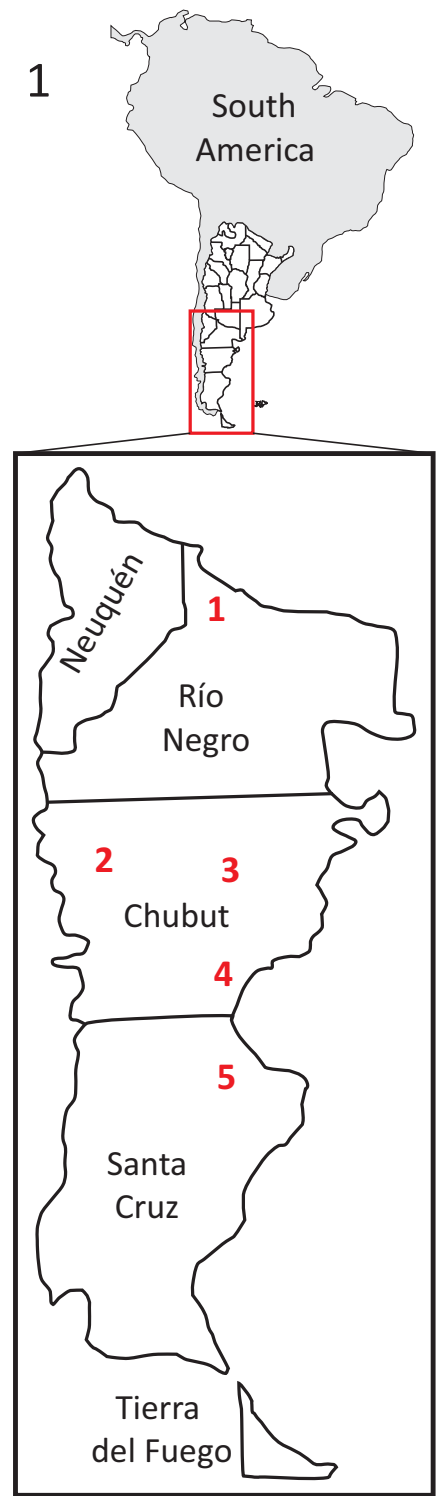

2
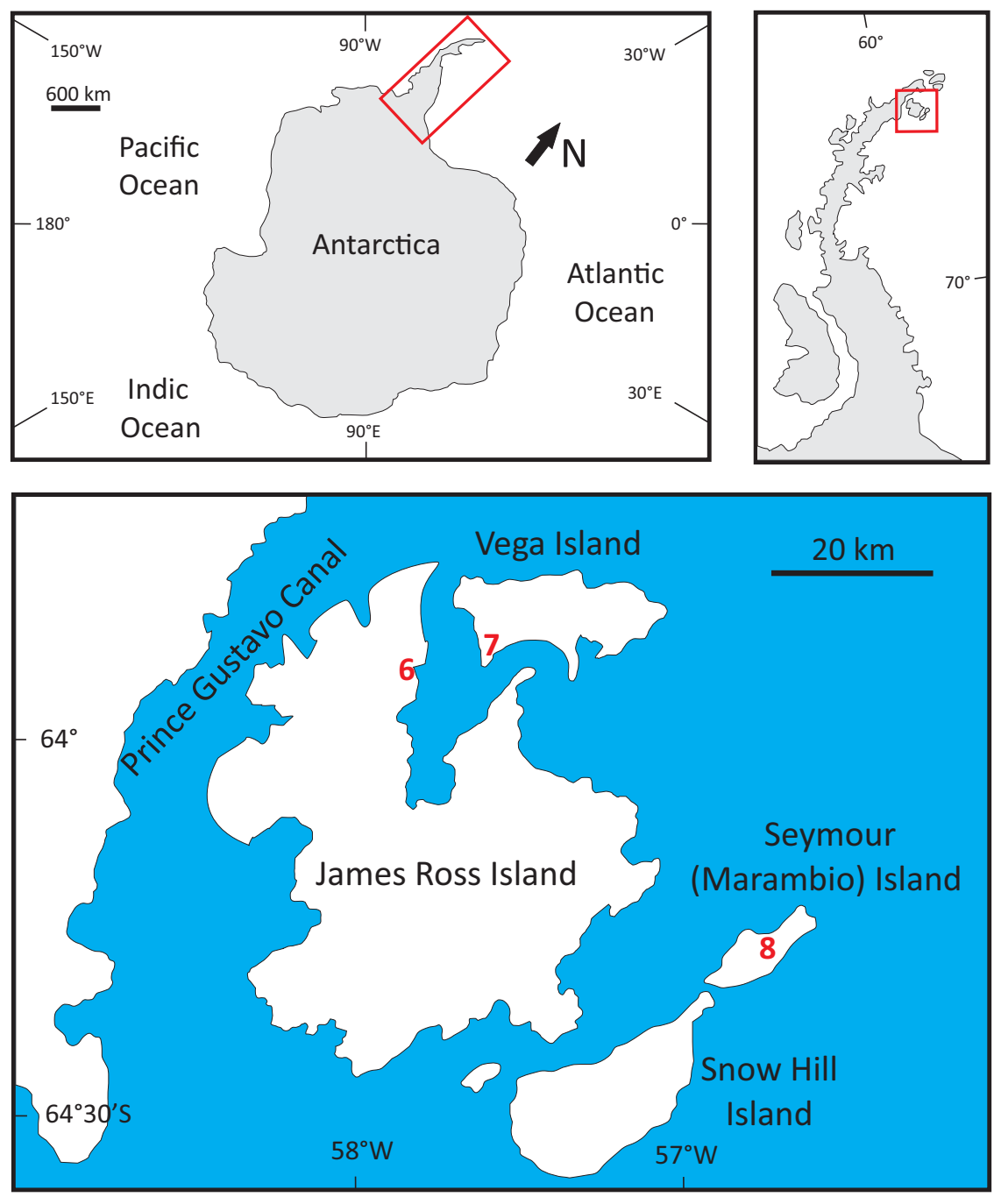

FIGURE 1. Location map showing the distribution of the occurrence of the materials mentioned in this contribution. 1. Detail of Patagonia. 2. Detail of Antarctic Peninsula. Abbreviations: 1: Neuquensaurus australis, N. robustus, Laplatasaurus araukanicus, Microcoelus patagonicus, "Titanosaurus" nanus; 2: Amygdalodon patagonicus; 3: Genyodectes serus; 4: Argyrosaurus superbus; 5: Wildeichnus navesi, Sarmientichnus scagliai, Delatorrichnus goyenechei; 6: Antarctopelta oliveroi and MLP 11-II-20-1; 7: MLP 99-I-10-1; 8: MLP 96-I-6-2.

1895; Roth, 1898; Cabrera, 1926, 1927, 1929; Berta and Marshall, 1978; Bond, 1986; Mones, 1986; Prevosti and Reguero, 2000) and birds (Acosta Hospitaleche et al., 2001). Regarding nonavian dinosaurs, no published catalogue actually exists for the Museo de La Plata. Lydekker (1893) and Huene (1929) presented seminal papers where all knowledge of that time about dinosaurs was virtually enclosed there. More recently, Bonaparte and Gasparini (1979) published a taxonomic contribution in which they specified lectotypes for some sauropods housed at MLP. Mones (1986) presented in his Catalogue of South American fossils a resume of the dinosaurs collected to that time. Finally, Otero (2010) presented all the available appendicular material of Neuquensaurus housed at MLP as an Appendix. The only catalogue that has been done for the MLP dinosaurs was performed in 1973 by sauropod specialist John McIntosh who created a hand-written catalogue of all the dinosaurs housed at MLP to that moment. However, the catalogue was never published. 
TABLE 1. Summary of the taxa presented in this contribution. Denotes missing at present.

\begin{tabular}{|c|c|c|c|c|c|}
\hline Systematic rank & Collection number & Horizon & Locality & Age & $\begin{array}{c}\text { Type/referred } \\
\text { material }\end{array}$ \\
\hline
\end{tabular}

\section{Saurischia}

Sauropodomorpha

Sauropoda

Amygdalodon

patagonicus

MLP 46-VIII-21-1/2 Cerro Carnerero

Formation

\begin{tabular}{|c|c|c|}
\hline $\begin{array}{l}\text { Laplatasaurus } \\
\text { araukanicus }\end{array}$ & $\begin{array}{c}\text { MLP-CS 1128, MLP- } \\
\text { CS } 1127\end{array}$ & $\begin{array}{l}\text { Anacleto Formation, } \\
\text { Colorado Subgroup }\end{array}$ \\
\hline $\begin{array}{l}\text { Microcoelus } \\
\text { patagonicus }\end{array}$ & MLP-Ly 23 & $\begin{array}{l}\text { Bajo de La Carpa } \\
\text { Formation, Río Color } \\
\text { Subgroup }\end{array}$ \\
\hline $\begin{array}{l}\text { "Titanosaurus" } \\
\text { nanus }\end{array}$ & MLP-Ly 18/19 & $\begin{array}{l}\text { Bajo de La Carpa } \\
\text { Formation, Río Color } \\
\text { Subgroup }\end{array}$ \\
\hline $\begin{array}{l}\text { Argyrosaurus } \\
\text { superbus }\end{array}$ & MLP 77-V-29-1 & $\begin{array}{l}\text { Bajo Barreal Formati } \\
\text { Chubut Group }\end{array}$ \\
\hline $\begin{array}{l}\text { Antarctosaurus } \\
\text { giganteus }\end{array}$ & MLP 26-316 & $\begin{array}{l}\text { Plottier Formation, } \\
\text { Neuquén Subgroup, } \\
\text { Neuquén Group }\end{array}$ \\
\hline Lithostrotia indet. & MLP 11-II-20-1 & Santa Marta Formati \\
\hline $\begin{array}{l}\text { Neuquensaurus } \\
\text { australis }\end{array}$ & MLP-Ly $1 / 2 / 3 / 4 / 5 / 6 / 7$ & Anacleto Formation \\
\hline $\begin{array}{l}\text { Neuquensaurus } \\
\text { robustus nomen } \\
\text { dubium }\end{array}$ & $\begin{array}{l}\text { MLP-CS 1095, MLP- } \\
\text { CS 1480, MLP-CS } \\
1171, \text { MLP-CS } 1094\end{array}$ & Anacleto Formation \\
\hline
\end{tabular}

The purpose of this contribution is to release an accurate, figured, and updated commented catalogue of the type material and Antarctic dinosaurs housed at the collection of the División Paleontología de Vertebrados at Museo de La Plata. According to the Recommendation $72 \mathrm{~F}$ of the International Code of Zoological Nomenclature (ICZN), the objective of this paper is to ensure an explicit labeling with an accurate format.
Cañadón Puelman, southwest from Cerro Carnerero, Sierra del Cerro Negro, Chubut Province, Argentina

Cinco Saltos and Lago Pellegrini, Rio Negro Province, Argentina

Right bank of the Río Neuquén, close to the city of Neuquén, Neuquén Province, Argentina

Right bank of the Río Neuquén, close to the city of Neuquén, Neuquén Province, Argentina

Left bank (northwest) of Campanianthe Río Chico, near Pampa Pelada, northeast of Lake Colhué Huapi, Chubut Province, Argentina

Aguada del Caño, Neuquén Province, Argentina

ConiacianSantonian

Two femora, two fragments of a pubis, distal end of a tibia, two incomplete caudal vertebrae as well as indeterminate fragments (holotype)

$\begin{array}{lll}\begin{array}{l}\text { Santa Marta Cove, } \\ \text { northern James Ross } \\ \text { Island, Antarctica }\end{array} & \begin{array}{l}\text { Upper } \\ \text { Campanian }\end{array} & \begin{array}{l}\text { Incomplete caudal } \\ \text { vertebra }\end{array} \\ \text { Neuquén Province } & \begin{array}{l}\text { Lower } \\ \text { Campanian }\end{array} & \begin{array}{l}\text { Sacrum and caudal } \\ \text { vertebrae (holotype) }\end{array} \\ \text { Neuquén Province } & \begin{array}{l}\text { Lower } \\ \text { Campanian }\end{array} & \begin{array}{l}\text { Right ulna, left ulna, } \\ \text { left radius, left femur } \\ \text { (lectotype) }\end{array}\end{array}$

\section{BRIEF HISTORY}

After the creation of the Museo de La Plata in 1884, its director, Dr. Francisco Pascasio Moreno, invited the Argentinean naturalist Florentino Ameghino to work in the Institution. Between his private collection (which was moved to La Plata), there were few bones collected from the current city of General Roca (Río Negro Province). Those bones, later attributable to the genus "Titanosaurus," constituted the first dinosaurs remains housed 
TABLE 1 (continued).

Systematic rank Collection number Horizon $\quad$ Locality $\quad$ Age $\begin{gathered}\text { Type/referred } \\ \text { material }\end{gathered}$

Theropoda

Genyodectes

serus

MLP 26-39

MLP 86-X-28-1

Gamma Member of the Santa Marta Formation, Marambio Group

MLP 99-I-10-1

Sandwich Bluff Member of Eastern flank of the López de Bertodano Formation

MLP 96-I-6-2

Unit K1B 9 of the López de Bertodano Formation

indet.

Ichnospecies

Theropoda

Wildeichnus navesi

MLP 60-X-31-5 La Matilde Formation

Sarmientichnus scagliai

Ornithischia

Delatorrichnus goyenechei
MLP 60-X-31-6 La Matilde Formation
Santa Marta Cove, North James Ross Island, Antarctica

Sandwich Bluff, Vega island, Antarctica

Seymour (Marambio) Island, Antarctica

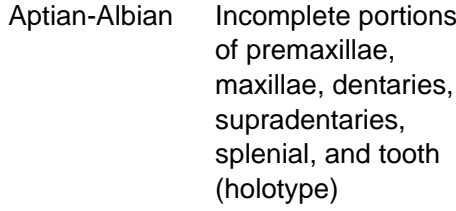
of premaxillae, maxillae, dentaries, supradentaries, splenial, and tooth (holotype)

$$
\begin{array}{ll}
\text { Upper } & \text { Partial skeleton, } \\
\text { Campanian } & \begin{array}{l}
\text { including cranial } \\
\text { remains (holotype) }
\end{array}
\end{array}
$$

$\begin{array}{ll}\begin{array}{l}\text { Upper-lower } \\ \text { Maastrichtian }\end{array} & \text { Cheek tooth* } \\ \text { Upper-lower } & \text { Distal end of } \\ \text { Maastrichtian } & \text { metatarsal }\end{array}$

Laguna Manantiales ranch, Santa Cruz Province, Argentina Laguna Manantiales ranch, Santa Cruz Province, Argentina

Middle Jurassic- Cast of an isolated lower Upper left pes (holotype) Jurassic

Middle Jurassic- Impression of an lower Upper isolated right foot Jurassic (holotype)

Laguna Manantiales ranch, Santa Cruz Province, Argentina

Middle Jurassic- Trackway with manus lower Upper and pes impressions Jurassic in a South American scientific institution (Salgado, 2007, p. 5).

With successive expeditions carried out by the Museo de La Plata to Patagonia, many dinosaur bones were collected. In an effort to obtain a comprehensive assessment of the growing collection of the DPV of Museo de La Plata, Moreno contacted Richard Lydekker to study the fossils housed there, between 1893 and 1894. Lydekker's travel to Argentina was important because he recognized the existence of a family of dinosaurs, the "Titanosauridae." The studies carried out by Lydekker were the first ones on Patagonian Mesozoic reptiles, denoting the fossil reptilian richness of Patagonia. The species erected and described by
Lydekker were "Titanosaurus" australis (=Neuquensaurus australs), "Titanosaurus" nanus, Argyrosaurus superbus, and Microcoelus patagonicus, as well as theropod remains (Lydekker, 1893).

Between 1896 and 1898, the chief of the Paleontology Department of the Museo de La Plata, Santiago Roth, collected reptile remains from the "Middle" Cretaceous of Chubut Province and sent to Arthur Smith Woodward, who recognized a carnivorous dinosaur who named Genyodectes serus (Woodward, 1901; Rauhut, 2004; Salgado, 2007).

In 1921, the Museo de La Plata carried out a field work to the dinosaur-bearing sediments in Patagonia during which were collected numerous dinosaur specimens. The latter were studied by 
Friedrich Von Huene (1929), who also made a revision of some specimens studied previously by Lydekker, describing and erecting many new sauropod taxa. The Museo de La Plata published in its "Anales," Los saurisquios y ornitisquios del Cretáceo argentino, a volume that includes Huene's main results and is one of the fundamental publications on South American dinosaurs of that time.

The DPV collection at MLP encloses virtually all the knowledge on South American dinosaurs of that time. Besides considering those materials previously studied by Ameghino, Smith, Woodward, and Lydekker, Huene described many others, identifying four new saurischian species, "Titanosaurus" robustus (materials from Cinco Saltos), Laplatasaurus araukanicus (materials from Cinco Saltos, General Roca, and Rancho de Ávila), Antarctosaurus giganteus (those materials from General Roca mentioned by Richard Wichmann, in 1916), and Campylodon ameghinoi (a partial sauropod maxilla found by Carlos Ameghino in the Sierra de Bernardo, in the current Province of Chubut), and one new ornithischian, Loricosaurus scutatus (a series of dermal plates from the locality of Cinco Saltos, later attributed to sauropods by Powell, 1980).

Later, in 1947, Cabrera erected Amygdalodon patagonicus, a sauropod based upon some fragmentary remains from upper Lower Jurassic deposits of Chubut Province.

After a hiatus of more than 30 years, the dinosaur material at MLP was taken up by Bonaparte and Gasparini (1979) who made a taxonomic revision and specified lectotypes for some species of sauropod dinosaurs. Finally, the most recent investigator that occasionally worked with dinosaurs was Dr. Rodolfo Casamiquela, who briefly described basal sauropodomorphs and basal sauropods from Patagonia as well as three ichnospecies (Casamiquela, 1963, 1964, 1980).

\section{Institutional Abbreviations}

Av, Ráncho de Ávila collection.

CS, Cinco Saltos collection.

MACN, Museo Argentino de Ciencias Naturales "Bernardino Rivadavia," Ciudad Autónoma de Buenos Aires, Buenos Aires Province (Argentina).

DPV, División Paleontología de Vertebrados.

Ly, Lydekker collection.

MLP, Museo de La Plata, La Plata, Buenos Aires Province (Argentina).

PVL, Instituto "Miguel Lillo," San Miguel de Tucumán, Tucumán Province (Argentina).

\section{PROCEDURE}

This catalogue includes all available information about the dinosaur types housed at the collection of DPV. The information includes: systematic hierarchy, taxon name, author and year, typological category, catalogue number, referred material, updated stratigraphic and geographic provenance, as well as any comments regarding the actual status of the taxon.

The systematics used herein follows the wellestablished general scheme proposed by several authors. In this sense, Dinosauria is a monophyletic group composed by the two major clades Saurischia and Ornithischia (Novas, 1996; Sereno, 1997, 1999; Benton, 2004). The phylogenetic relationships within Dinosauria are presented in Figure 2. Saurischia comprises both Theropoda and Sauropodomorpha (Benton, 2004). Within Sauropodomorpha, the phylogenetic relationships of basal sauropodomorphs considered herein follows the proposals of Yates $(2003,2004)$ and Pol et al. (2011) in which "Prosauropoda" is regarded as paraphyletic. Sauropoda is a stem-based monophyletic group (Upchurch et al., 2004) composed by basal forms (e.g., vulcanodontids) and Neosauropoda, which includes Diplodocoidea and Macronaria (Wilson and Sereno, 1998). Theropod phylogenetic relationships follows Holtz et al. (2004), recognizing Ceratosauria and Tetanurae as the two main clades, the latter composed by Spinosauroidea and Avetheropoda. The systematic arrangement of Ornithischia presented here follows Butler et al. (2008) in which two major clades of ornithischians are recognized: Thyreophora and Neornithischia, both enclosed in Genasauria (Sereno, 1986). For the in-group relationships of Ankylosauria the scheme of Thompson et al. (2012) was followed.

Taxonomic definitions follow those of Sereno (1998) unless otherwise stated.

Regarding the stratigraphic nomenclature, the original nomination is presented for each taxon, although an updated scheme was given where appropriate. For sediments of the Neuquén Basin, we followed the scheme of Leanza et al. (2004) for the Lower Cretaceous beds, and that of Garrido (2010) for the Upper Cretaceous beds. For sediments of the Chubut Group the scheme of Prosepio (1987) was followed.

Double quotes will be used when a generic name is no longer valid. 

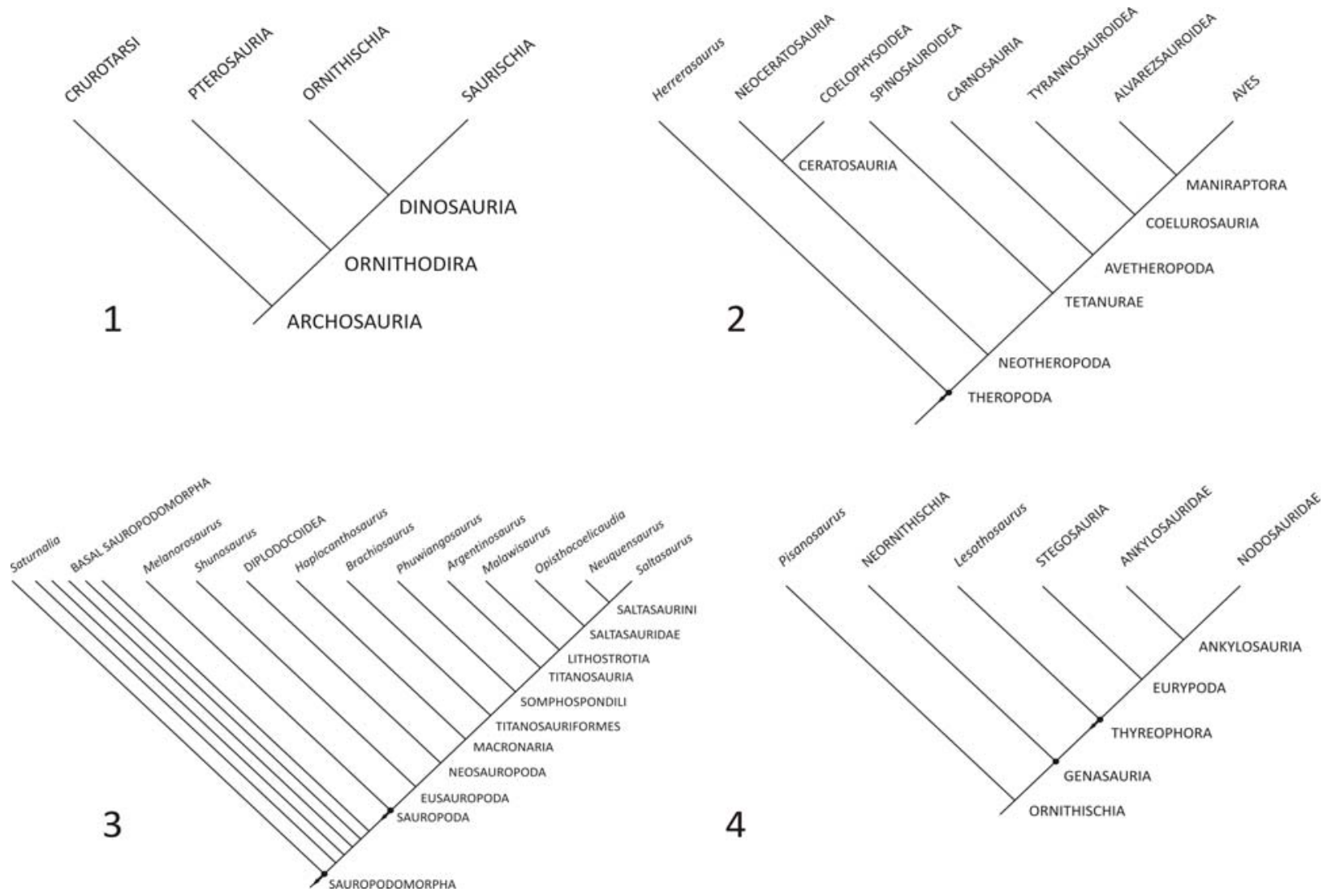

FIGURE 2. Phylogenetic relationships of dinosaurs. 1. Simplified relationships of archosaurs (adapted from Benton, 2004). 2. Phylogenetic relationships of Theropoda (adapted from Holtz et al., 2004). 3. Phylogenetic relationships of Sauropodomorpha (adapted from Yates, 2003; Pol et al., 2011;Carballido et al., 2011; D'Emic, 2012). 4. Phylogenetic relationships of Ornithischia (adapted from from Butler et al., 2008).

\section{SYSTEMATIC PALEONTOLOGY}

DINOSAURIA Owen, 1842

SAURISCHIA Seeley, 1888

SAUROPODOMORPHA von Huene, 1932

Sauropodomorpha are terrestrial herbivores that achieved the largest body masses in a range of time from the Late Triassic to Late Cretaceous (Galton and Upchurch, 2004; Upchurch et al., 2004). Sauropodomorph remains have been recovered in all terrestrial landmasses including Antarctica (Hammer and Hickerson, 1994; Galton and Upchurch, 2004; Smith and Pol, 2007; Cerda et al., 2011). Sauropodomorpha is regarded here as a stem-based sister group of Theropoda (sensu Yates, 2007b). Sauropoda is the most diverse and abundant sauropodomorph group, whose monophyly is well established (McIntosh, 1990; Upchurch et al., 2004; Wilson, 2002) and is defined as the most inclusive clade containing Saltasaurus (stem-based) but not Melanorosaurus (Yates, 2007a, 2007b). In turn, Sauropoda is composed by a set of basal forms (e.g., Shunosaurus, Patagosaurus) and the well-established node-based Neosauropoda, which includes Diplodocoidea (i.e., diplodocoids and rebbachisaurids) and Macronaria (i.e., brachiosaurids and somphospondylans) (Carballido et al., 2011; D'Emic, 2012).

SAUROPODA Marsh, 1878

Genus AMYGDALODON Cabrera, 1947

Type species. Amygdalodon patagonicus Cabrera, 1947

Lectotype. MLP 46-VIII-21-1/2, posterior dorsal vertebra (Rauhut, 2003) (Figure 3).

Referred material. MLP 46-VIII-21-1/1 and MLP 46-VIII-21-1/3 through 11 (vertebral and rib remains), MLP 46-VIII-21-1/12, MLP 46-VIII-21-1/ 13, MLP 46-VIII-21-1/15, MLP 46-VIII-21-1/12 17 and MLP 46-VIII-21-1/12 18 (tooth crowns), MLP 46-VIII-21-1/12 14 and MLP 46-VIII-21-1/12 16 (stem-based roots), MLP 46-VIII-21-1/19 (right pubis), MLP 36-XI-10-3/1 (posterior dorsal vertebrae with attached dorsal rib) (Carballido and Pol, 2010). 

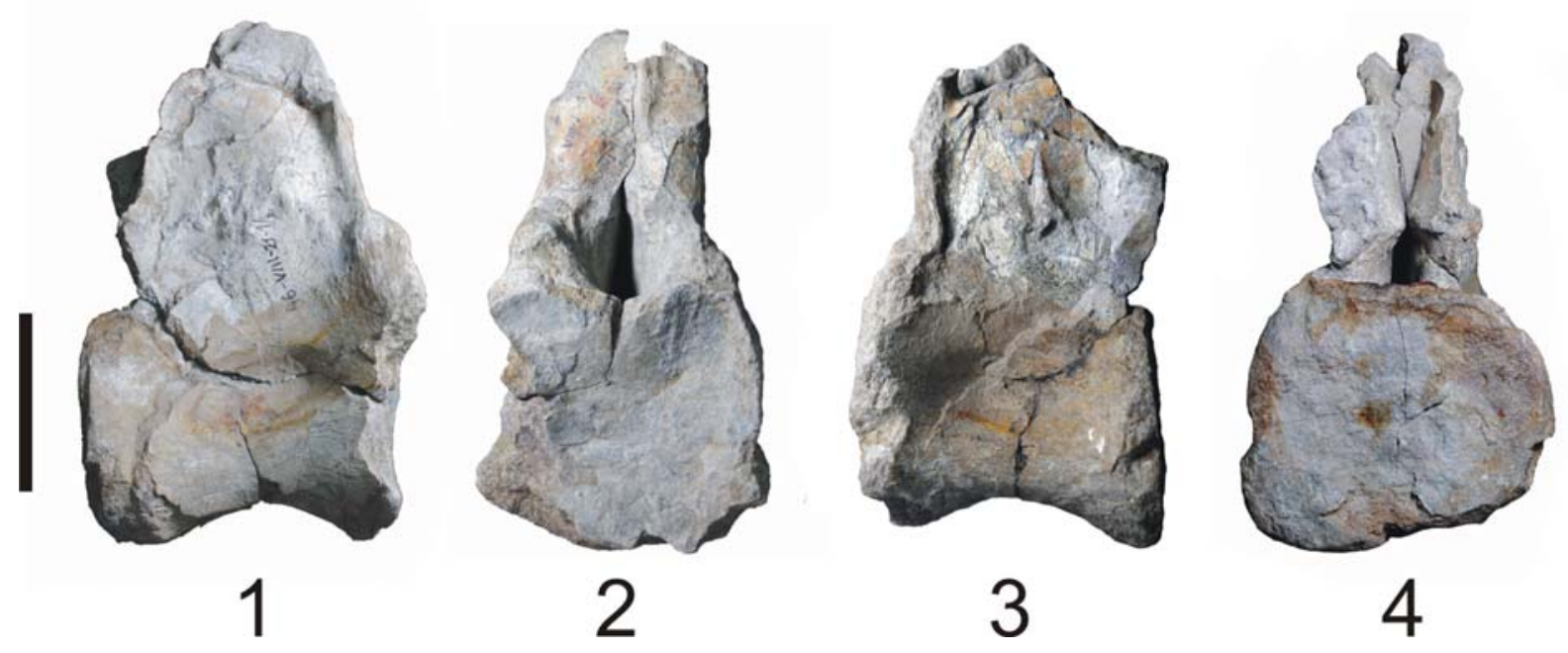

FIGURE 3. Amygdalodon patagonicus (lectotype). Posterior dorsal vertebra (MLP 46-VIII-21-1/2) in right lateral (1), anterior (2), left lateral (3), and posterior (4) views. Scale bar equals $100 \mathrm{~mm}$.

Locality and age. Cañadón Puelman, southwest from Cerro Carnerero, Sierra del Cerro Negro, Chubut Province, Argentina. Cerro Carnerero Formation (Late Toarcian to Early Aalenian (Rauhut, 2003).

Comments. Amygdalodon patagonicus is the stratigraphically oldest South American sauropod. Previous systematic assignments include it within "Cetiosauridae" (sensu Lydekker, 1888) (Cabrera, 1947; Casamiquela, 1963). Wilson (2002) regarded $A$. patagonicus as a member of Eusauropoda together with Patagosaurus and more derived sauropods upon the basis of the 'cervical rib positioned ventrolateral to centrum' (Wilson, 2002, p.267). Rauhut (2003) also placed this species within Eusauropoda based on several features present in the lectotype as well as in the referred specimens of $A$. patagonicus, although lacking synapomorphic traits that define higher eusauropod clades. The features listed by Rauhut (2003) as synapomorphic of Eusauropoda and present in A. patagonicus include, among others, the height of the dorsal neural arches being equal to or exceeding the height of the centrum and teeth with spatulate crown, wrinkled enamel, presence of $\mathrm{V}$ shaped wear-facets and well-developed grooves on the labial surfaces of the crown paralleling the crown margins (Rauhut, 2003, p. 180). On the other hand, Upchurch et al. (2004) regarded it as Eusauropoda incertae sedis.

Carballido and Pol (2010) incorporated Amygdalodon patagonicus in a phylogenetic analysis for the first time, including dental characters, diagnosing some unique combination of characters and an autapomorphy for this taxon (i.e., enamel wrinkled forming a pattern of pits and narrow apicobasal sulci) (Carballido and Pol, 2010, p. 84). This analysis led the authors to conclude that $A$. patagonicus lies outside Eusauropoda and that Amygdalodon conforms a polytomy together with Gongxianosaurus, Isanosaurus and Gravisauria (i.e., vulcanodontids + Eusauropoda sensu Allain and Aquesbi, 2008).

NEOSAUROPODA Bonaparte, 1986

MACRONARIA Wilson and Sereno, 1998

TITANOSAURIFORMES Salgado, Coria, and Calvo, 1997

TITANOSAURIA Bonaparte and Coria, 1993 LITHOSTROTIA Upchurch, Barrett and Dodson, 2004

(="Titanosauridae" sensu Salgado, Coria, and Calvo, 1997)

Genus LAPLATASAURUS von Huene, 1929

Type species. Laplatasaurus araukanicus Huene, 1929 (Bonaparte and Gasparini, 1979, p. 389; McIntosh, 1990, p. 395, 396; Upchurch et al., 2004, p. 269; Wilson and Upchurch, 2003, p. 143) v. 1986 "Titanosaurus" araukanicus (Powell, 1986, 2003).

v. 2002 "Titanosaurus" araukanicus (Wilson, 2002, p. 249).

Lectotype. MLP-CS 1128, right tibia and MLP-CS 1127, right fibula (Huene, 1929, pl. 27, figure 1, 2; Bonaparte and Gasparini, 1979) (Figure 4).

Hypodigm. MLP-CS 1316, cervical vertebra; MLPCS 1145/1131/1136/1146, dorsal vertebrae; MLPCS 1348/1315/1352; caudal vertebrae; MLP- 

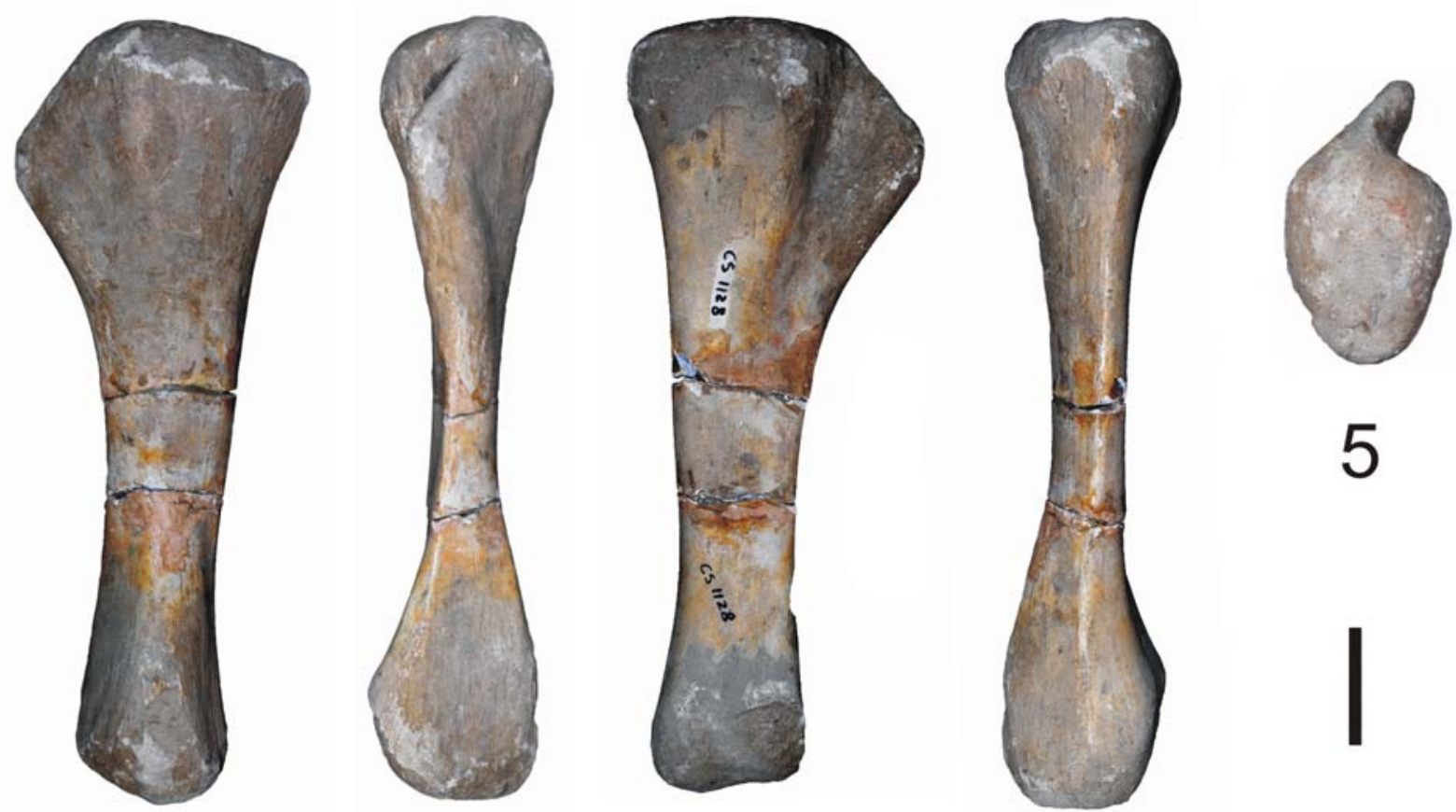

\section{5}
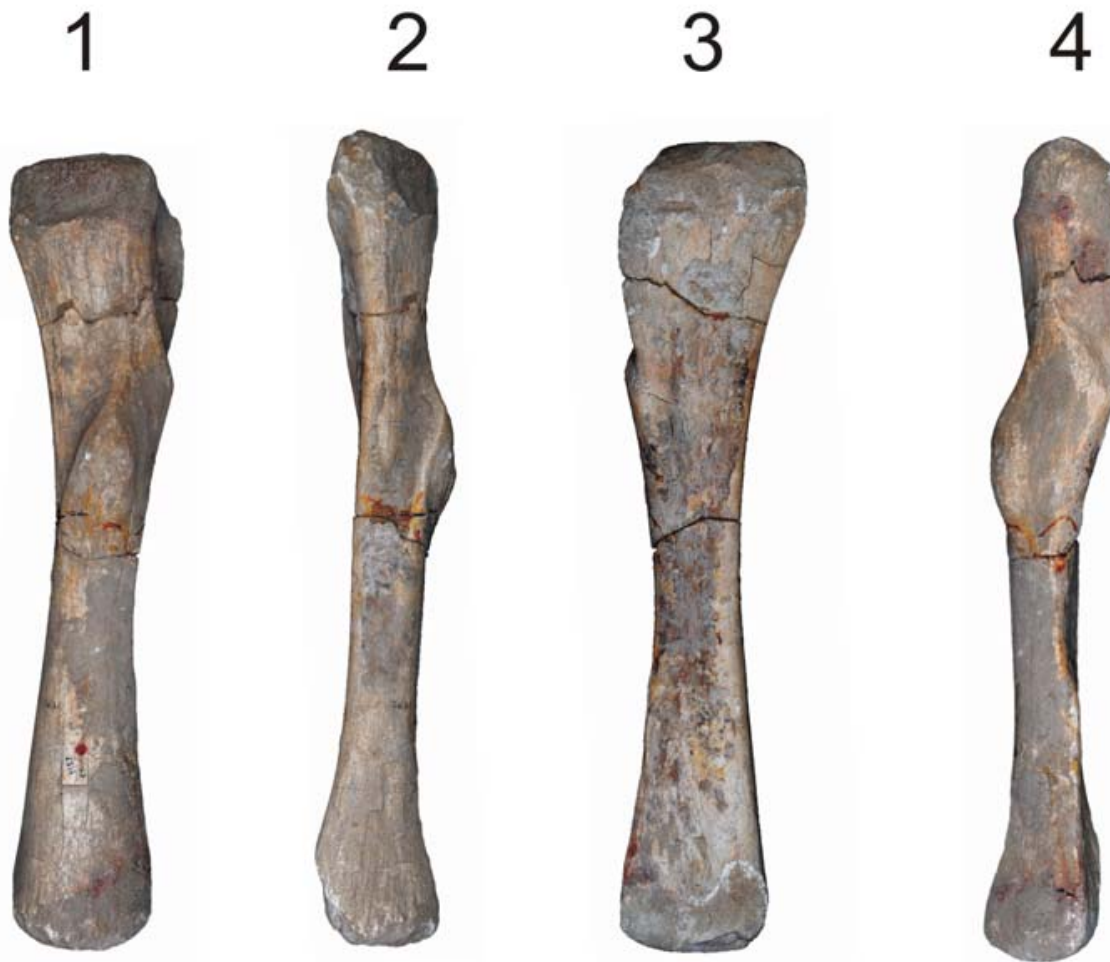

8

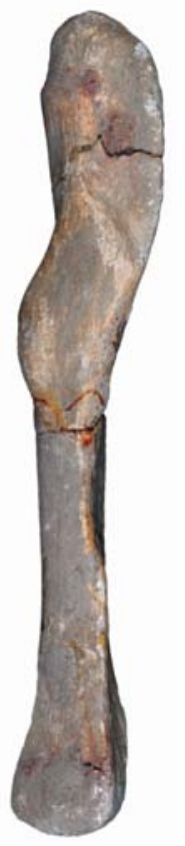

9

FIGURE 4. Laplatasaurus araukanicus (lectotype). Right tibia (MLP-CS 1128) in medial (1), anterior (2), lateral (3), posterior (4), and proximal (5, anterior towards top) views. Right fibula (MLP-CS 1127) in lateral (6), posterior (7), medial (8), and anterior (9) views. Scale bar equals $100 \mathrm{~mm}$. 
CS1031, right scapula; MLP-CS 1262, coracoids; MLP-CS 1322, left sternal plate; MLP-CS 1174, incomplete left humerus; MLP-CS 1299, left radius; MLP-CS 1170/1168/1192/1196, metacarpals; MLPCS 2002/1217, incomplete metacarpals; MLP-CS 1059, left pubis; MLP-CS 2202/2217, incomplete metatarsals (Huene, 1929; Powell, 2003, p. 22, 23; Salgado and Bonaparte, 2007, p. 208). Huene (1929, p. 56-58) also listed several remains, mostly caudal vertebrae, from Rancho de Ávila, Río Negro Province, as belonging to Laplatasaurus araukanicus, catalogued under MLP-Av.

Locality and age. Cinco Saltos and Lago Pellegrini, Río Negro Province. Río Colorado Subgroup (top of the Anacleto Formation) (Leanza, 1999), Lower Campanian (Leanza, 1999; Leanza and Hugo, 2001; Garrido, 2010).

Comments. As pointed out above, numerous materials were previously referred to Laplatasaurus araukanicus, even though their assignment is dubious. Huene (1929) noted that some elements previously referred by Lydekker (1893) to the genus "Titanosaurus" as well as other from Cinco Saltos were larger and more slender, erecting Laplatasaurus araukanicus as a distinct taxonomic entity. Huene (1929) presented an extensive list of materials from three different Argentinian quarries (i.e., Cinco Saltos, General Roca and Rancho de Ávila) as pertaining to $L$. araukanicus based upon the basis of its slender limb bones, although no diagnosis was given. Bonaparte and Gasparini (1979) specified a right fibula (MLP-CS 1127) and a right tibia (MLP-CS 1128) as the lectotype of $L$. araukanicus, considering this taxon generically distinct from "Titanosaurus" due to its gracile and slender condition. McIntosh (1990, p. 351) also listed additional fossil quarries where materials from $L$. araukanicus come from (i.e., Chubut and Salta Provinces). Wilson (2002, p. 249, 269) regarded $L$. araukanicus as a member of Saltasauridae (sensu Powell, 1992) based upon the presence of biconvex distal caudal centra, the distalmost biconvex caudal centra short and distal radius beveled dorsolaterally (see also Salgado and Bonaparte, 2007). Powell (2003) provided a diagnosis for this species and considered $L$. araukanicus as a taxon closely related to "Titanosaurus" indicus based on its size, robustness and general morphology; hence, he referred remains previously assigned to Laplatasaurus back to its former genus, as "Titanosaurus" araukanicus. Nonetheless, Powell $(2003$, p. 23, 24) reaffirmed its taxonomic separation from " $T$ ". indicus, mainly based on attributes of the caudal vertebrae (e.g., centra relatively much longer and laterally compressed in " $T$ ". indicus) and also the separation from derived titanosaurs (i.e., Saltasaurinae sensu Powell, 1992) which are smaller in size and display much more robustness on the limbs. Besides, Powell (2003) restricted the name "Titanosaurus" araukanicus to specimens coming from Cinco Saltos and Lago Pellegrini, regarding materials from other localities as "Titanosaurus" sp. Powell (2003, p. 23) listed the double lateral tuberosity of the fibula and aspects of the proportions of the bones as diagnostic of the genus Laplatasaurus. The latter, thus, was revalidated by Upchurch et al. (2004).

Genus MICROCOELUS Lydekker, 1893

Type species. Microcoelus patagonicus Lydekker, 1893 nomen dubium

Holotype. MLP-Ly 23, anterior dorsal vertebra (Figure 5).

Locality and age. Right bank of the Río Neuquén, close to the city of Neuquén (Powell, 2003). Bajo de La Carpa Formation (Río Colorado Subgroup, Neuquén Group), Late Cretaceous, Santonian (Garrido, 2010).

Comments. Powell (2003, p. 44, 45) considered Microcoelus patagonicus as nomen dubium because of the lack of diagnostic features. There is also a left humerus (MLP-Ly 25) that Lydekker (1893) referred to M. patagonicus; however this material resembles in morphology and proportions to those of Neuquensaurus australis (Huene, 1929. P. 37; Powell, 2003, p. 45; Otero, 2010, p. 406).

Genus "TITANOSAURUS" Lydekker, 1877

Type species. "Titanosaurus" nanus Lydekker, 1893 nomen dubium

Holotype. MLP-Ly 18/19, incomplete cervical and dorsal vertebrae (Figure 6).

Locality and age. Right bank of the Río Neuquén, between 2 and $4 \mathrm{~km}$ before the railway bridge which crosses this river, close to the city of Neuquén (Powell, 2003). Bajo de La Carpa Formation (Río Colorado Subgroup, Neuquén Group), Late Cretaceous, Santonian (Garrido, 2010).

Comments. As well as with Microcoelus patagonicus, there are not features that permits distinguish "Titanosaurus" nanus at generic or specific level due to the incompleteness of the material (Powell, 2003, p. 24; Wilson and Upchurch, 2003).

$$
\text { Genus ARGYROSAURUS Lydekker, } 1893
$$

Type species. Argyrosaurus superbus Lydekker, 1893 


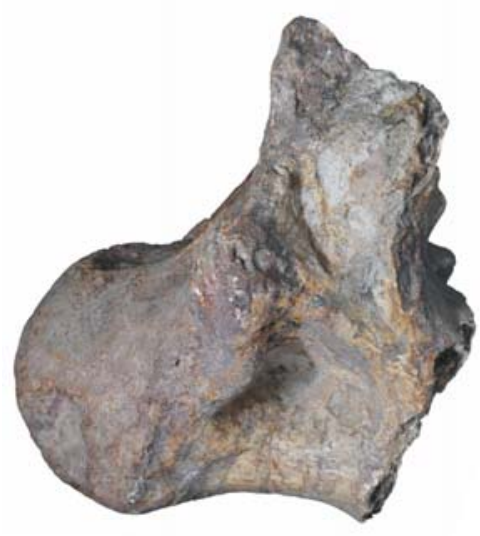

1
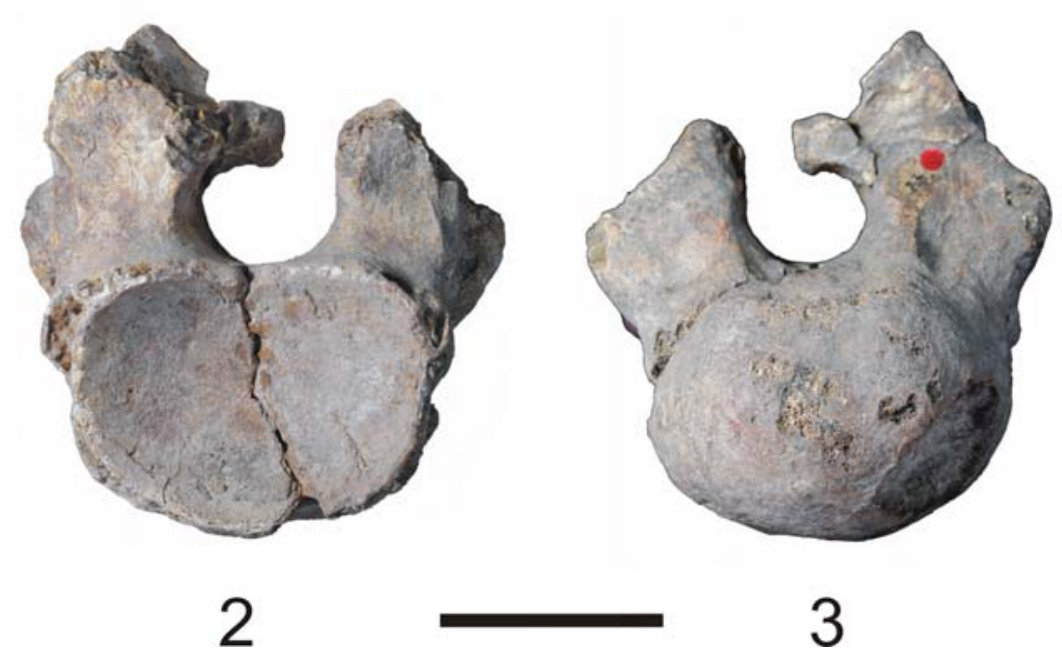

FIGURE 5. Microcoelus patagonicus nomen dubium (holotype). Anterior dorsal vertebra (MLP-Ly 23) in left lateral (1), posterior (2), and right lateral (3) views. Scale bar equals $100 \mathrm{~mm}$.

Holotype. MLP 77-V-29-1, left forelimb, including the humerus, radius, ulna, and five metacarpals (Figure 7).

Locality and age. Pampa Pelada, northeast of Lake Colhué Huapi, Chubut Province, Argentina (Lydekker, 1893; Huene, 1929; Bonaparte and Gasparini, 1979; Mannion and Otero, 2012); upper member of the Bajo Barreal Formation, Chubut Group (Bonaparte and Gasparini, 1979; Casal et al., 2007); Cenomanian-Turonian in age (Bridge et al., 2000) or Campanian-Maastrichtian (Casal et al., 2007; see also Salgado and Bonaparte, 2007; Ibiricu et al., 2010; Prieto-Márquez and Salinas, 2010).

Referred material. Several remains from Argentina and Uruguay were formerly referred to Argyrosaurus by previous authors (Lydekker, 1893, Huene, 1929; Bonaparte and Gasparini, 1979; Powell, 2003). None of them are housed at Museo de La Plata. A complete revision and assignment of those materials are given in Mannion and Otero (2012).

Comments. From all the materials previously assigned to Argyrosaurus only MLP 77-V-29-1 was considered as belonging species (Mannion and Otero, 2012). Previous treatments on Argyrosaurus superbus lack a diagnosis (Lydekker, 1893) or that is vague without the specification of autapomorphies. Autapomorphic features and unique combination of characters for Argyrosaurus superbus are provided for the first time by Mannion and Otero (2012). The position of $A$. superbus within basal Titanosauria is based on the preservation of carpal bones (although currently missed) and the longest metacarpals are Mc. II and III, a feature that Argyrosaurus shares with the putative basal titanosaur Janenschia (Mannion and Otero, 2012). Although previous phylogenetic assignments of Argyrosaurus also considered it within basal titanosaurs (Sanz et al., 1999; Wilson, 2002), those were made upon the basis of the referred materials (e.g., PVL-4628 and MACN-CH 217), (Mannion and Otero, 2012).

The holotype of Argyrosaurus superbus was completely restored and is currently shown at the exhibition of Museo de La Plata.

\section{Genus ANTARCTOSAURUS Huene, 1929}

Type species. Antarctosaurus giganteus Huene, 1929

Holotype. MLP 26-316, two femora (Figure 8), two fragments of a pubis, distal end of a tibia, two incomplete caudal vertebrae as well as indeterminate fragments.

Locality and age. Aguada del Caño, $15 \mathrm{~km}$ to the north of China Muerta, Department of Confluencia, Neuquén Province. Plottier Formation (Neuquén Subgroup, Neuquén Group), Late Cretaceous, Coniacian-Santonian (Powell, 2003; Garrido, 2010).

Comments. Antarctosaurus giganteus is a controversial taxon since Powell (2003) and Bonaparte and Gasparini (1979) agrees that $A$. giganteus is a valid species although most probably pertain to a different genus. Upchurch et al. (2004) nonetheless regarded this species as a nomen dubium since it is based on incomplete material and no autapomorphies define it. The two holotypic femora of this species are mounted at the exhibition of the MLP. 

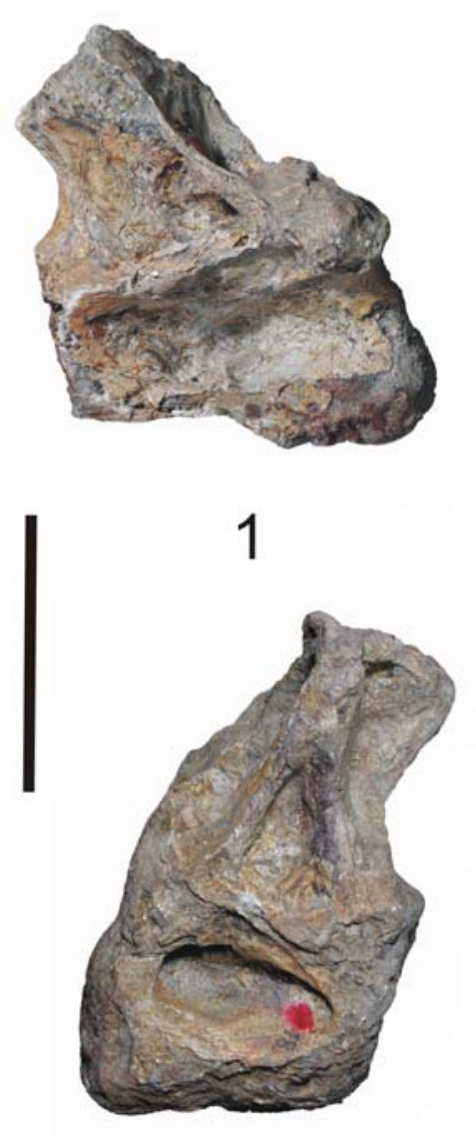

4

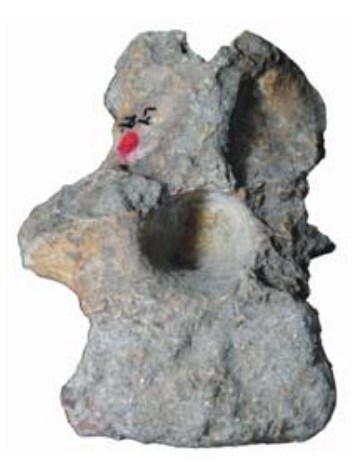

2

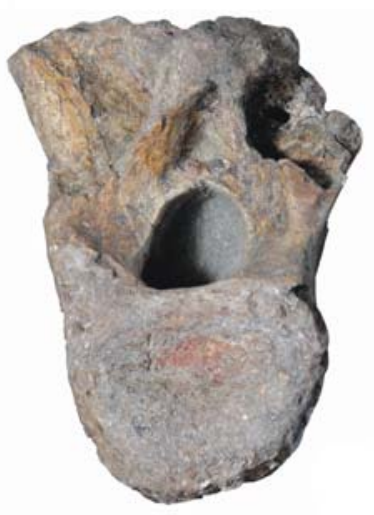

5

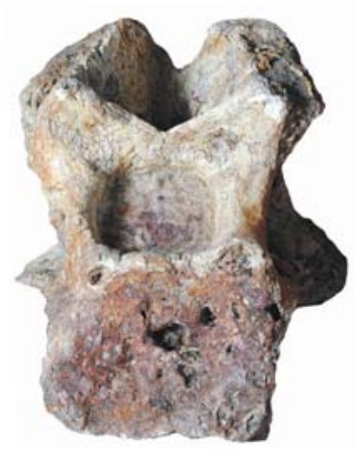

3

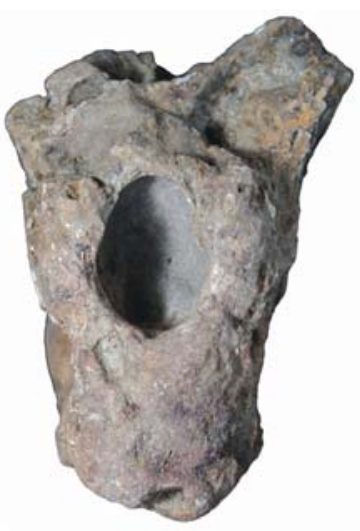

6

FIGURE 6. "Titanosaurus" nanus nomen dubium (holotype). Cervical vertebra (MLP-Ly 19) in right lateral (1), posterior (2), and anterior (3) views. Dorsal vertebra (MLP-Ly 18) in left lateral (4), posterior (5), and anterior (6) views. Scale bar equals $100 \mathrm{~mm}$.

\section{GEN. ET SP. INDETERMINATE}

Material. MLP 11-II-20-1, incomplete caudal vertebra (Figure 9).

Locality and age. Shallow marine shelf deposits from Upper Campanian (Santa Marta Formation), from Santa Marta Cove, northern James Ross Island (Cerda et al., 2011)

Comments. Although rather fragmentary, the single element presented by Cerda et al. (2011) constitutes the first record of a sauropod dinosaur from the Antarctic Peninsula. Despite the fact that the material is not complete, some diagnostic attributes can be noted, as the anterior position of the neural arch, which places the specimen within Titanosauriformes, and the procoely of the referred middle caudal vertebra links the specimen to Lithostrotia (Cerda el al., 2011).

SALTASAURINI Salgado and Bonaparte, 2007 (=Saltasaurinae Powell, 2003)
Saltasaurini includes the most derived titanosaur sauropods, from the Late Cretaceous of Patagonia and north of Argentina. Powell $(1992,2003)$ originally includes here Neuquensaurus (="Titanosaurus") australis and Saltasaurus loricatus under Saltasaurinae. Later, Salgado et al. (1997, p. 24) define Saltasaurinae as the clade including the more recent common ancestor of Neuquensaurus australis and Saltasaurus loricatus.' Subsequently, Rocasaurus muniozi Salgado and Azpilicueta, 2000 and Bonatitan reigi Martinelli and Forasiepi, 2004 were included in this clade. Sereno (1998) changed the definition of Saltasaurinae to 'all saltasaurids closer to Saltasaurus than to Ophisthocoelicaudia,' including under this definition many other taxa such as Aeolosaurs rionegrinus and Alamosaurus sanjuanensis, not included originally in the definition of Saltasaurinae by Powell (2003). Consequently, Salgado and Bonaparte (2007) pro- 

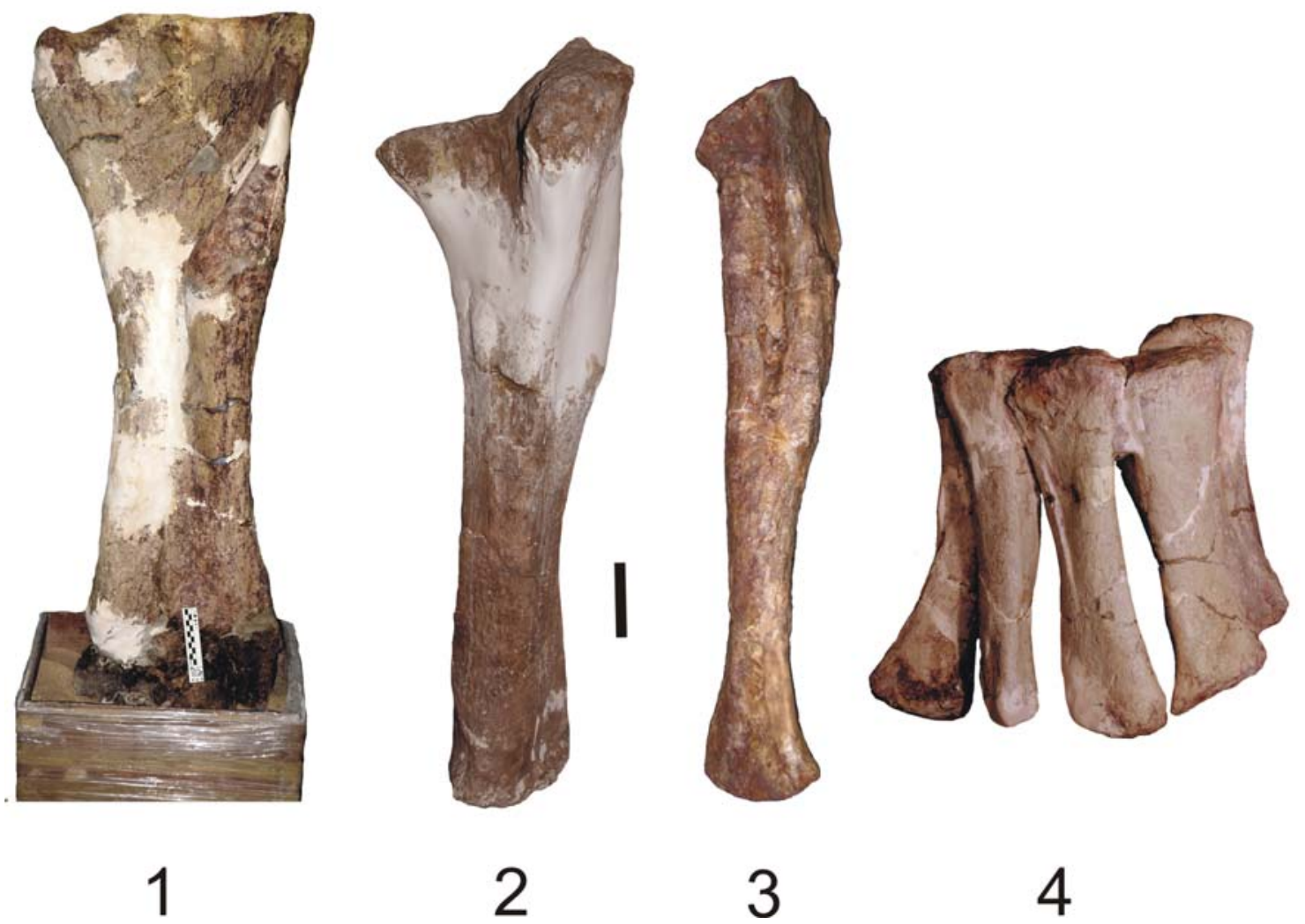

FIGURE 7. Argyrosaurus superbus, holotype (MLP 77-V-29-1). 1. Left humerus in anterior view. 2. Left ulna in anterolateral view. 3. Left radius in posterior view. 4. Left metacarpus in anterior view. Scale bar equals $100 \mathrm{~mm}$.

posed Saltasaurini (=Saltasaurinae sensu Salgado et al., 1997; Powell, 2003): 'the least inclusive clade containing Saltasaurus loricatus and Neuquensarus australis.'

Genus NEUQUENSAURUS (Lydekker, 1893)

Type species. "Titanosaurus" australis Lydekker, 1893

v. 1990 Saltasaurus australis (McIntosh, 1990).

Holotype. MLP-Ly 1/2/3/4/5/6/7, sacrum and caudal vertebrae (Lydekker, 1893; D'Emic and Wilson, 2011) (Figure 10).

Referred Specimens. Numerous postcranial bones including vertebrae, girdles and limbs belonging to several individuals (Lydekker, 1893; Huene, 1929; Powell, 2003; Otero, 2010). The vertebral remains were arranged by Huene (1929) by "Series from Neuquén" and "Series from Cinco Saltos," the former composed by three series and the later composed by four series. The appendicular material were reexamined in detail by Otero (2010), reassigning several bones (see below).

Locality and age. The holotype material as well as all the referred remains studied by Lydekker (1893) and Huene (1929) and housed at MLP come from
Neuquén Province. Lamentably, Lydekker did not specify the precise geographic location of the find or data of the stratigraphic position. The materials studied by Huene (1929) come from General Roca and Cinco Saltos ("Gobernación de Río Negro," currently homonym Province), from strata belonging to the "Dinosaurierschichten" (strata with dinosaurs, Keidel, 1917). These strata belong to Anacleto Formation (Senonense inferior sensu Huene, 1929, p. 11), Lower Campanian (Garrido, 2010).

Comments. The original holotype material of " $T$ ". australis included six caudal vertebrae (Lydekker, 1893). D'Emic and Wilson (2011) identified the existence of congruent matrix deposits on the articular surfaces of the first caudal vertebrae and the last sacral vertebrae of the sacrum MLP-Ly 7, recognizing the sacrum and the six caudals as belonging to the same individual, increasing the holotype of Neuquensaurus australis.

Neuquensaurus robustus (Huene, 1929)

Type species. V. 1990 Saltasaurus robustus (McIntosh, 1990) nomen dubium. 


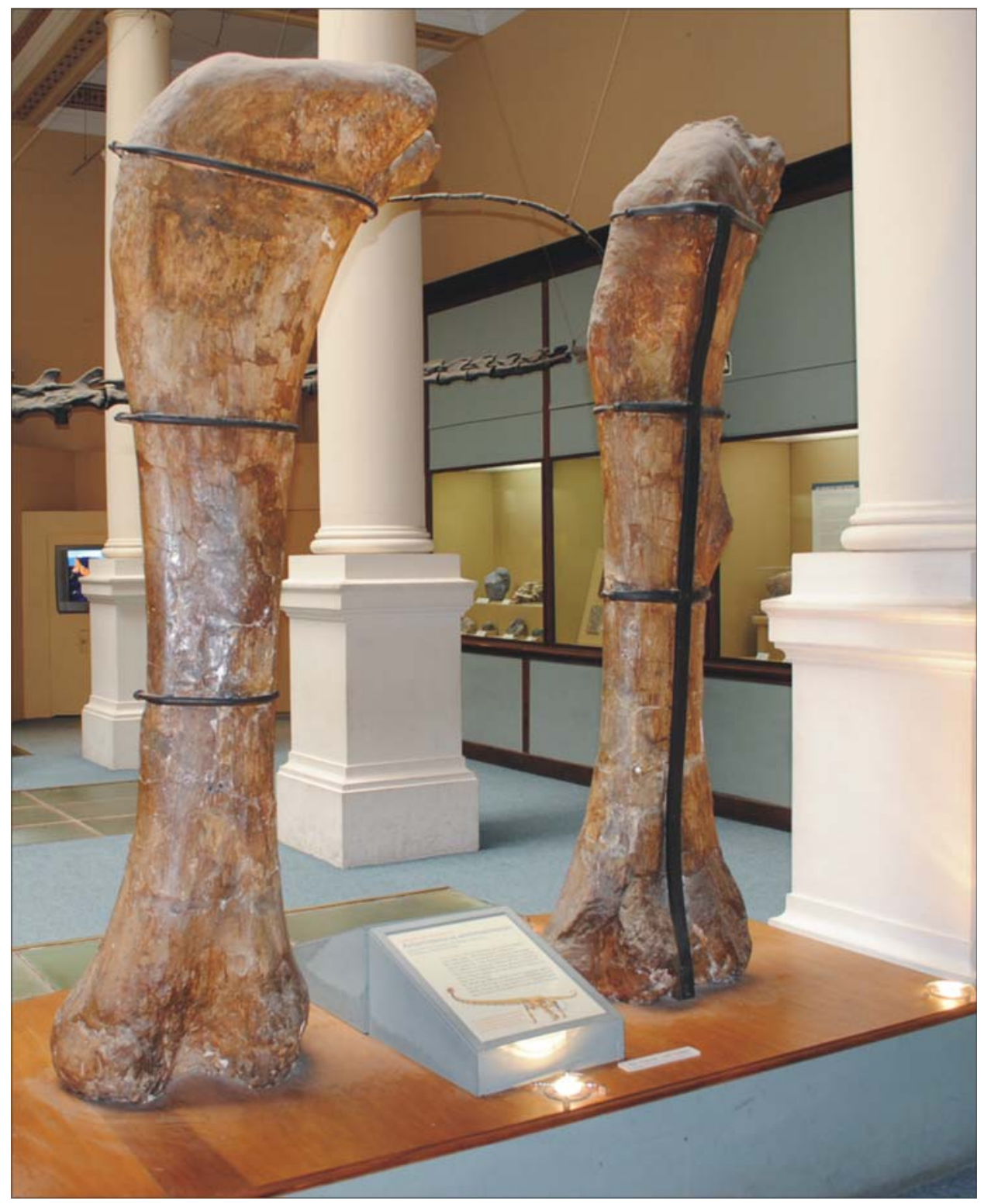

FIGURE 8. Antarctosaurus giganteus (holotype). Femora (MLP 26-316) exhibited on display at the MLP.

Lectotype. MLP-CS 1095, right ulna; MLP-CS 1094, left ulna; MLP-CS 1171, left radius; MLP-CS 1480, left femur (Huene, 1929; Bonaparte and Gasparini, 1979; Powell, 2003; Otero, 2010) (Figure 11).

Referred Specimens. Numerous postcranial bones including vertebrae, girdles and limbs (see Powell, 2003, p. 44; Otero, 2010).

Locality and age. The same as for Neuquensaurus australis.

Comments. Huene (1929) recognized Neuquensaurus (="Titanosaurus") robustus based on the relative robustness of the limb bones relative to "Titanosaurus" australis, but no type material was assigned. Later, Bonaparte and Gasparini (1979) specified lectotypes for those materials. Powell (2003) did not recognize differences between $N$. australis and $N$. robustus; hence he regarded the latter as nomen dubium. More recently, Otero (2010, p. 418, 419) reviewed the appendicular remains of both species and concluded that 'many of the multiple specimens described by Lydekker (1893) and Huene (1929) seem to pertain to a single individual; others, to a single genus and even species. However, several elements described by those authors as "Titanosaurus" robustus probably belong to the type species, "Titanosaurus" australis, and vice versa. On the other hand, the status of 


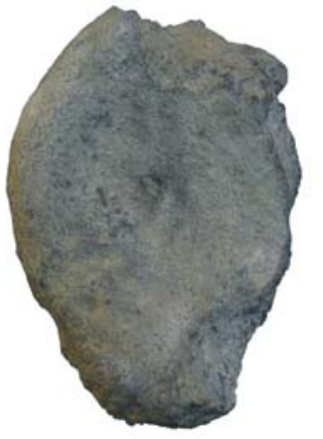

1

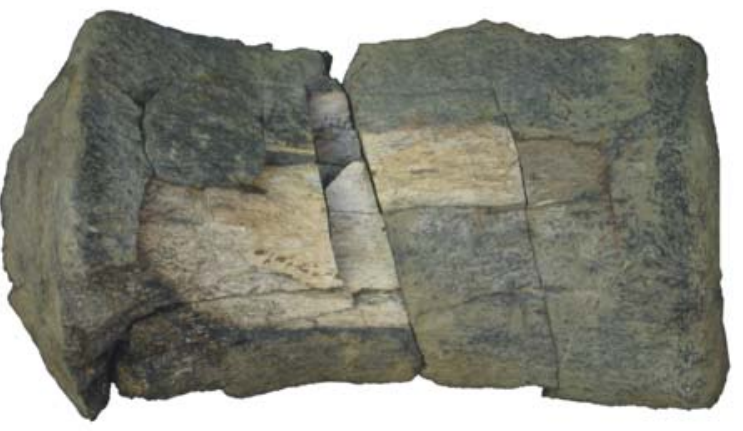

2
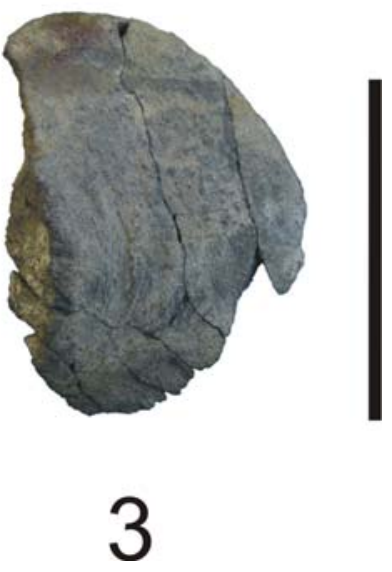

FIGURE 9. Lithostrotia gen. et sp. ideterminate. Caudal vertebrae (MLP 11-II-20-1) in anterior (1), right lateral (2) and posterior (3) views. Scale bar equals $100 \mathrm{~mm}$.

others cannot really be determined: they may belong to the type species, or they may represent another species or even genus' (Otero, 2010, p. 418, 419). Further studies on Neuquensaurus robustus that include the vertebral material will clarify its definitive taxonomic status.

\section{THEROPODA Marsh, 1881}

Theropods include the carnivorous, biped dinosaurs, which inhabited all continents and can be found in terrestrial beds, in a range of time between the Late Triassic (Carnian) to Late Cretaceous. Theropoda is a stem-based group defined as 'all saurischians more closely related to Neornithes than to Saltasaurus' (Sereno, 1998). With the exception of basal forms with no established phylogenetic relationships, such as Herrerasaurus (Ezcurra, 2010; Nesbitt, 2011), theropod dinosaurs are nested within Neotheropoda, in which two

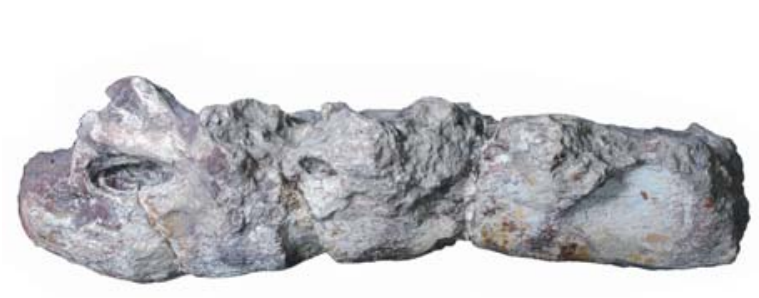

1

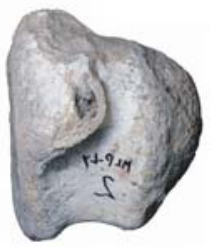

4

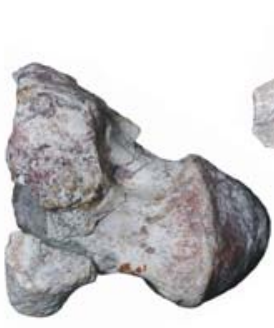

5

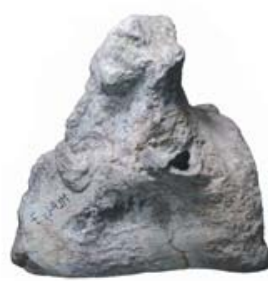

2

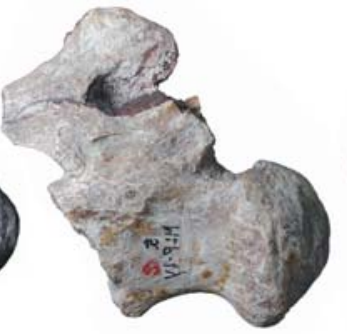

6

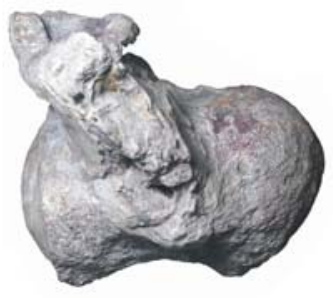

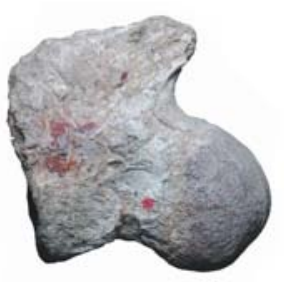

7
3

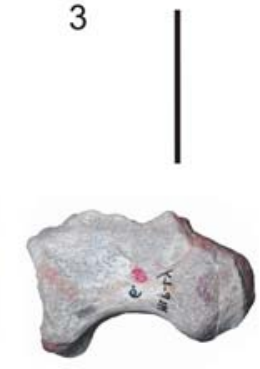

8

FIGURE 10. Neuquensaurus australis (holotype). 1. Sacral vertebrae 1-5 (MLP-Ly 7). 2. Sacral vertebrae 5 and 6 (MLP-Ly 7). 3. Neuquensaurus (MLP-Ly 1). 4. Anterior caudal vertebra (MLP-Ly 2). 5. Anterior caudal vertebra (MLPLy 3). 6. Anterior caudal vertebra (MLP-Ly 4). 7. Anterior caudal vertebra (MLP-Ly 5). 8. Middle caudal vertebra (MLPLy 6). All elements are in right lateral view (reversed). Scale bar equals $100 \mathrm{~mm}$. 


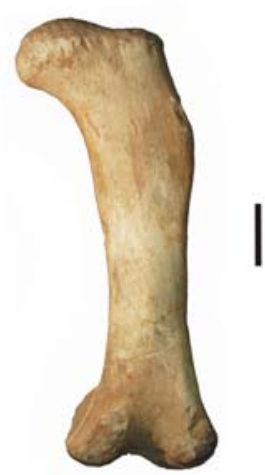

1

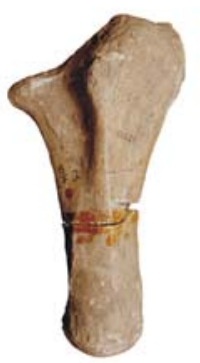

7

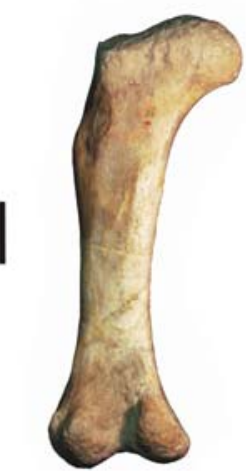

2

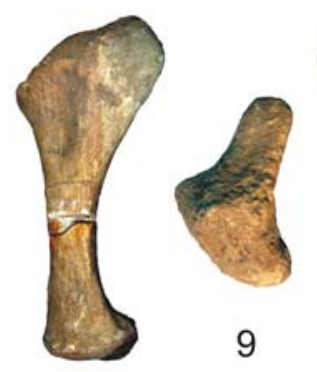

8

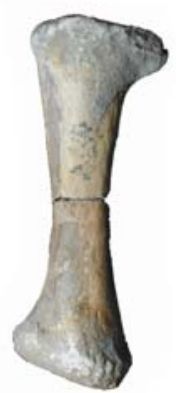

3

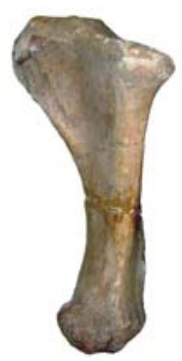

10

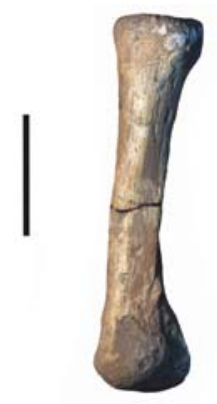

4

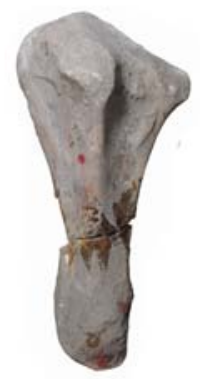

11

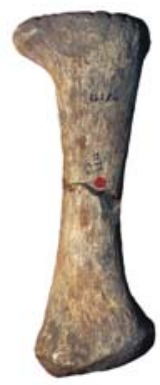

5

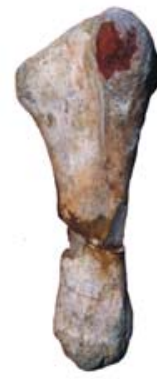

12

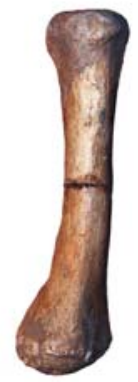

6

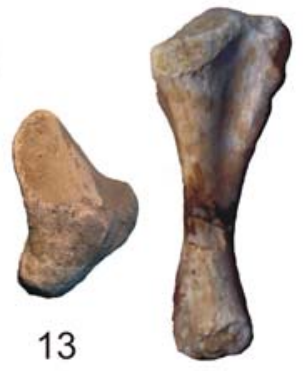

14

FIGURE 11. Neuquensaurus robustus (lectotype). Left femur (MLP-CS 1480) in anterior (1) and posterior (2) views. Left radius (MLP-CS 1171) in posterior (3), lateral (4), anterior (5), and medial (6) views. Left ulna (MLP-CS 1094) in lateral (7), posterolateral (8), proximal (9, anterior towards top), and anteromedial (10) views. Right ulna (MLP-CS 1095) in lateral (11), posteromedial (12), proximal (13, anterior towards top), and anteromedial (14) views. Scale bar equals $100 \mathrm{~mm}$.

major clades are recognized: Ceratosauria and Tetanurae. The former comprises the non-avian theropods and the latter encloses the theropods in the line to crown-group birds (Tykoski and Rowe, 2004; Holtz et al., 2004).

NEOTHEROPODA Bakker, 1986

CERATOSAURIA Marsh, 1884

CERATOSAURIA insertae sedis

Genus GENYODECTES Woodward, 1901

Type species. Genyodectes serus Woodward, 1901

Holotype. MLP 26-39, incomplete premaxillae united to the anteroventral sections of the maxillae, and the anterior half of both dentaries, bearing upper and lower teeth, parts of both supradentaries and fragments of the left splenial (Woodward, 1901) (Figure 12).

Locality and age. Cañadón Grande, Department of Paso de Indios, Chubut Province, Cerro Castaño Member, Cerro Barcino Formation, Aptian-Albian, Lower Cretaceous (Rauhut, 2004; Coria, 2007).
Comments. Genyodectes serus was the first nonavian theropod described in South America. Despite its unquestionable theropod affinities, Genyodectes was regarded as a member of a variety of theropod groups, as megalosaurids (Huene, 1929), tyrannosaurids (Huene, 1932; Maleev, 1974) and abelisaurids (Paul, 1988), although no convincing argue was given. On the other hand, Tykosky and Rowe (2004) considered Genyodectes as nomen dubium. Rauhut (2004) made a deep revision of the materials and identify a combination of features that relates Genyodectes with Ceratosauria (e.g., presence of a flat or even slightly concave area adjacent to the marginal carinae in the lateral teeth, completely fused interdental plates, extreme transverse flattening of the lateral maxillary crowns, extreme length of the maxillary tooth crowns). The latter author considers Genyodectes as a valid taxon although notes the difficulty of placing this taxon within Ceratosauria confidently.

ORNITHISCHIA Seeley, 1888

GENASAURIA Sereno, 1986 

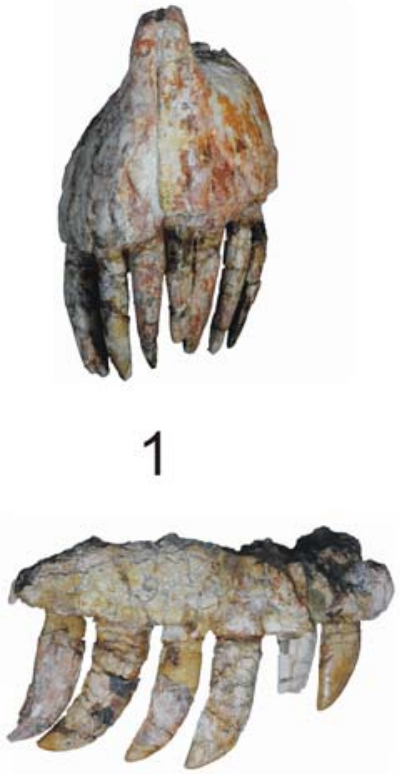

5

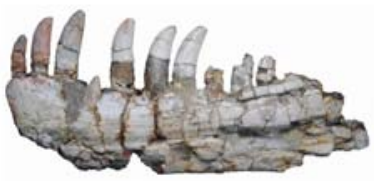

9

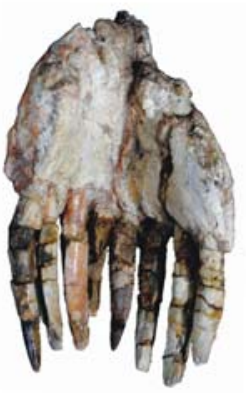

2

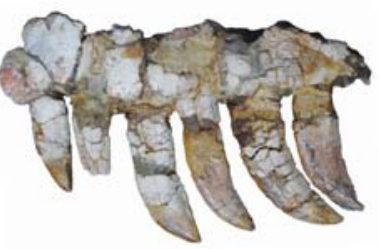

6

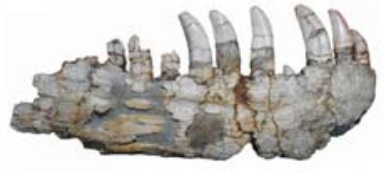

10

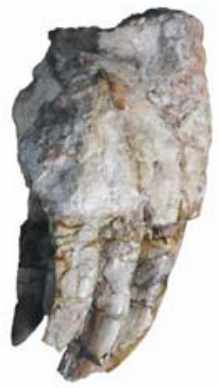

3

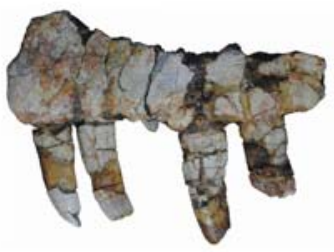

7

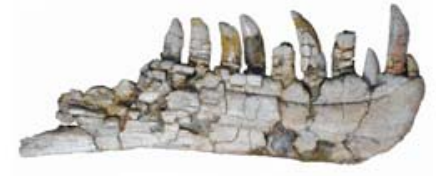

11

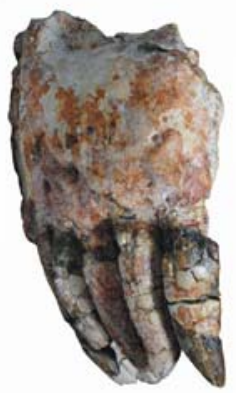

4

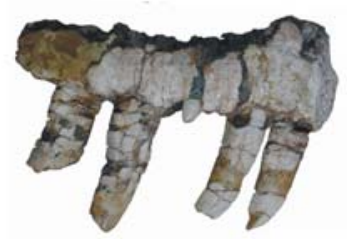

8

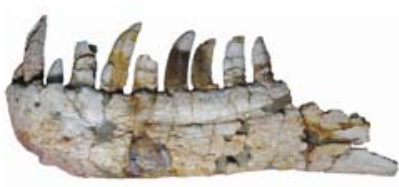

12

FIGURE 12. Genyodectes serus (holotype) (MLP 26-39). Premaxilae in anterior (1), posterior (2), right lateral (3) and left lateral (4) views. Right maxilla in lateral (5) and medial (6) views. Left maxilla in lateral (7) and medial (8) views. Right dentary in medial (9) and lateral (10) views. Left dentary in medial (11) and lateral (12) views. Scale bar equals $100 \mathrm{~mm}$.

\section{THYREOPHORA Nopsca, 1915}

\section{ANKYLOSAURIA Osborn, 1923}

Ankylosauria comprises a clade of quadrupedal herbivorous ornithischians dinosaurs with a global record and a temporal range from the Middle Jurassic to Upper Cretaceous (Vickaryous et al., 2004; Thompson et al., 2012), defined (stembased) as 'all eurypods (Ankylosauria + Stegosauria) closer to Ankylosaurus than to Stegosaurus' (Sereno, 1998). Ankylosaurs are characterized by the possession of parasagittal and transverse rows of osteoderms covering the dorsum and the presence of ornamented armored skulls (Vickaryous et al., 2004; Thompson et al., 2012). Ankylosauria comprises thyreophoran oornithischians and constitutes the sister group of Stegosauria with whom compose Eurypoda (Sereno, 1986; Vickaryous et al., 2004; Thompson et al., 2012). The interrelationships within Ankylosauria are not well established because the impossibility of identifying cranial sutures due to the presence of the cranial ornamentation and the conservative postcranial bauplan among the clade (Thompson et al., 2012). Nonetheless, two distinct clades are well recognized within Ankylosauria: Ankylosauridae, with broad-snouted skulls and tail club, and Nodosauridae, with elongated skulls and lacking tail club (Sereno, 1986; Vickaryous et al., 2004; Thompson et al., 2012).

NODOSAURIDAE Marsh, 1890

Genus ANTARCTOPELTA Salgado and Gasparini, 2006

Type species. Antarctopelta oliveroi Salgado and Gasparini, 2006

Holotype. MLP 86-X-28-1, partial skeleton consisting of a fragment of left dentary with an in situ tooth, three isolated teeth, a collection of fragmentary cranial ossifications, two cervical vertebrae, and a latex cast prepared from a natural mould of three articulated cervical vertebrae, about eight 

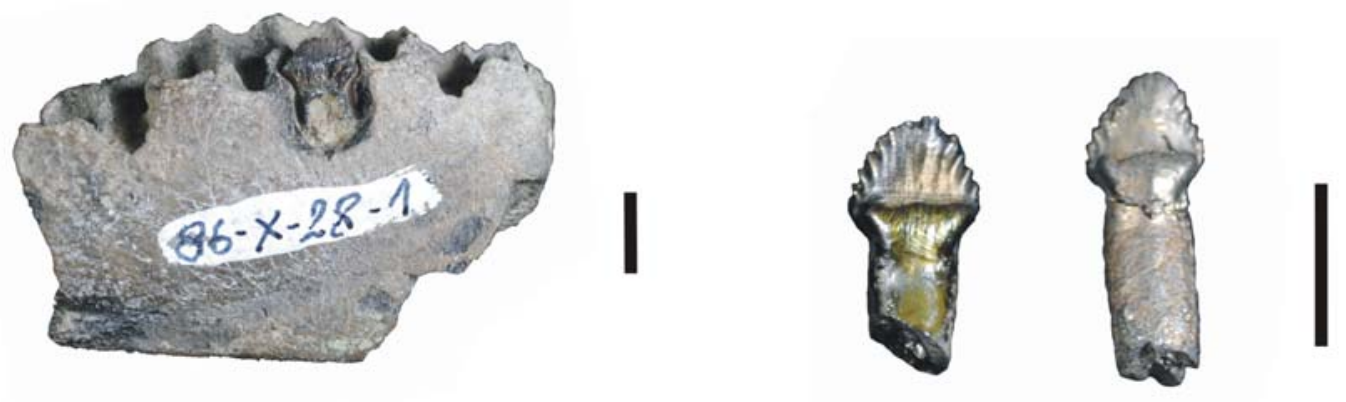

1

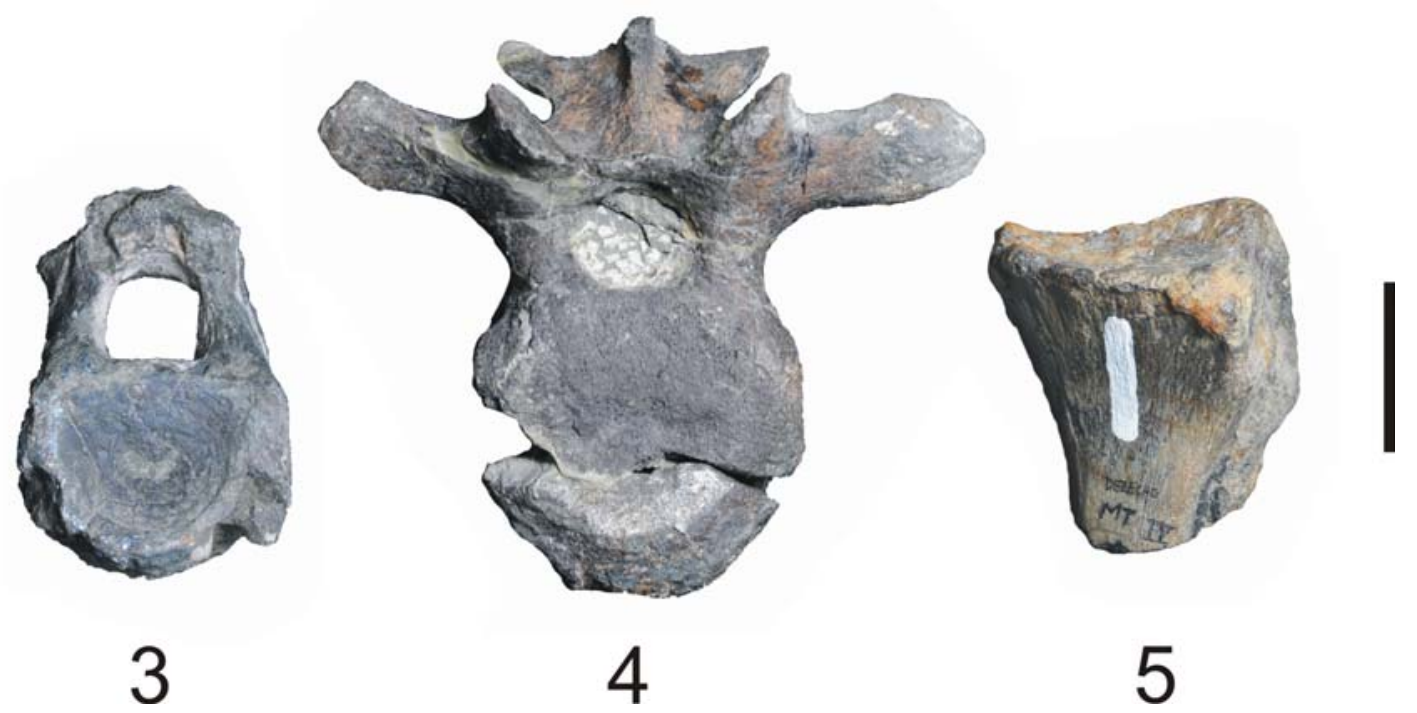

FIGURE 13. Antarctopelta oliveroi, holotype (MLP 86-X-28-1). Partial. 1. Left dentary in medial view. 2. Teeth. 3. Anterior cervical vertebra in anterior view. 4. Posterior cervical vertebra in anterior view 5. Right IV? metatarsal in ventral view. Scale bar equals $10 \mathrm{~mm}$ in 1 and 2, and $3 \mathrm{~mm}$ in 3, 4 and 5 .

fragments of dorsal ribs, two dorsal centra representing part of the presacral rod, a partial sacrum composed of three sacral centra, eight incomplete caudal vertebrae, the proximal (glenoid) portion of the left scapula, a fragment of the right ilium, a distal fragment of a left femur, five metapodials, two phalanges, and a collection of six different morphotypes of osteoderms (Figure 13).

Locality and age. Santa Marta Cove, North James Ross Island, Antarctica, locality D6-1 (Gasparini et al., 1987; Olivero et al., 1991; Salgado and Gasparini, 2006). Lower part of the Gamma Member of the Santa Marta Formation (Marambio Group) (Upper Campanian) (Olivero et al,. 1991; Olivero, 1992).
Comments. Salgado and Gasparini (2006) discussed the affinities of $A$. oliveroi to both Ankylosauridae and Nodosauridae although regarded it as Ankylosauria indet. due to the presence of a mosaic of characters widely distributed among both ankylosaurian families (e.g., poorly developed cingulum on teeth III, lateral projections of the cranial ornamentation, presence of a tail club, pelvic shield formed by a strongly joined elements). Recently, Thompson et al. (2012) considered A. oliveroi as the basalmost member of Nodosauride. However, because the fragmentary condition of this taxon, its definitively systematic placement is an open question. 


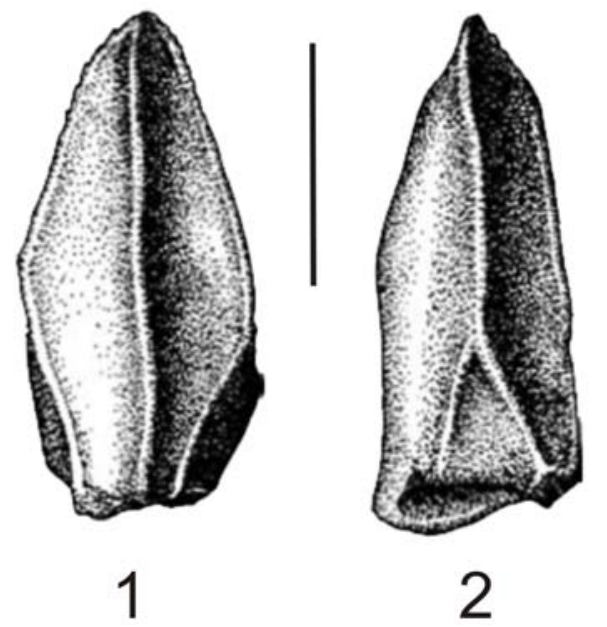

FIGURE 14. Hadrosauridae indet. (MLP 99-I-10-1). Tooth in occlusal (1) and side (2) views. Scale bar equals $10 \mathrm{~mm}$. (adapted from Case et al., 2000).

\section{ORNITHOPODA Marsh, 1881 HADROSAURIDAE Cope, 1869 HADROSAURINAE? Lambe, 1918}

Collection number. MLP 99-I-10-1, cheek tooth (Figure 14).

Locality and age. Sandwich Bluff Member, López de Bertodano Formation; "Reptile Horizon" on the eastern flank of Sandwich Bluff, Vega island, Antarctica (Case et al., 2000).

Comments. The material MLP 99-I-10-1 represents the first hadrosaurian dinosaur reported from Antarctica (Case et al., 2000). At present, this material is missing.

\section{HADROSAURIDAE?}

Collection number. MLP 96-I-6-2, distal end of metatarsal (Figure 15).

Locality and age. Seymour (Marambio) Island, Antarctica. Unit K1B 9 sensu Macellari (1988) of the López de Bertodano Formation, Late Cretaceous (upper-Lower Maastrichtian) (Rich et al., 1999; Olivero et al., 2007).

Comments. The material MLP 96-I-6-2, although well preserved, is very incomplete; hence, its assignment to Hadrosauridae is not conclusive (Rich et al., 1999).

$$
\begin{gathered}
\text { ICHNOTAXA } \\
\text { Ichnogenus DELATORRICHNUS Casamiquela, } \\
1964
\end{gathered}
$$

Type ichnospecies. Delatorrichnus goyenechei Casamiquela, 1964

Holotype. MLP 60-X-31-6, trackway with manus and pes impressions (Figure 16.1).

Paratypes. MLP 60-X-31-7.

Referred specimens. MLP 60-X-31-1, MLP 65-XI12-1/1, MLP 65-XI-12-1/2 and MLP 65-XI-12-1/3.

Locality and age. Laguna Manantiales, Santa Cruz Province, Argentina. La Matilde Formation ("Matildense" sensu Casamiquela, 1964), upper Middle Jurassic-lower Upper Jurassic (Riccardi and Damborenea, 1993; de Valais, 2011 and references therein).

Comments. The ichnospecies was established by Casamiquela (1964) and later revised by the same author (Casamiquela, 1966). The new evidence shows a manus with three toes, with digit III being the longest. The manus is bigger than the foot. Delatorrichnus was a quadrupedal animal, originally attributed to coelurosaurian dinosaurs (Casamiquela, 1964), although is now accepted an ornithischian affinities for this ichnotaxon (Bonaparte, 1996; De Valais, 2011).

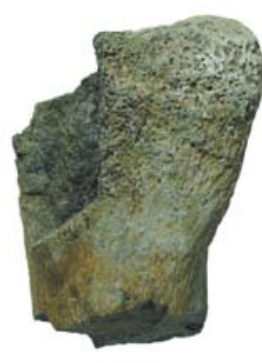

1

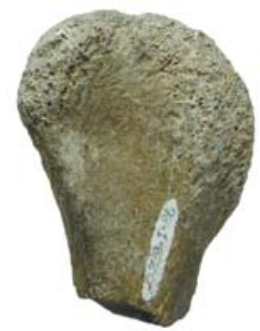

2

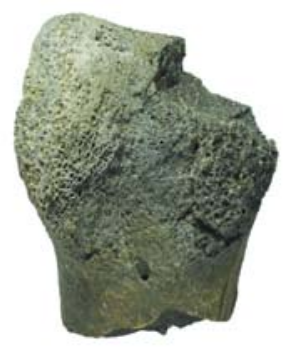

3

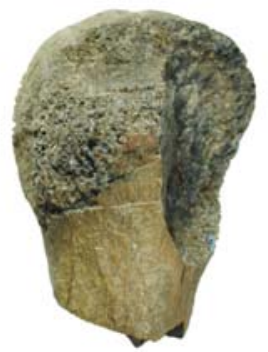

4

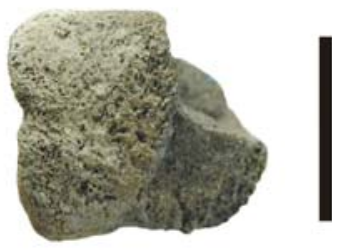

5

FIGURE 15. Hadrosauridae? (MLP 96-I-6-2). Distal end of metatarsal in dorsal (1), lateral or medial (2), ventral (3), lateral or medial (4), and distal (5) views. Scale bar equals $50 \mathrm{~mm}$. 


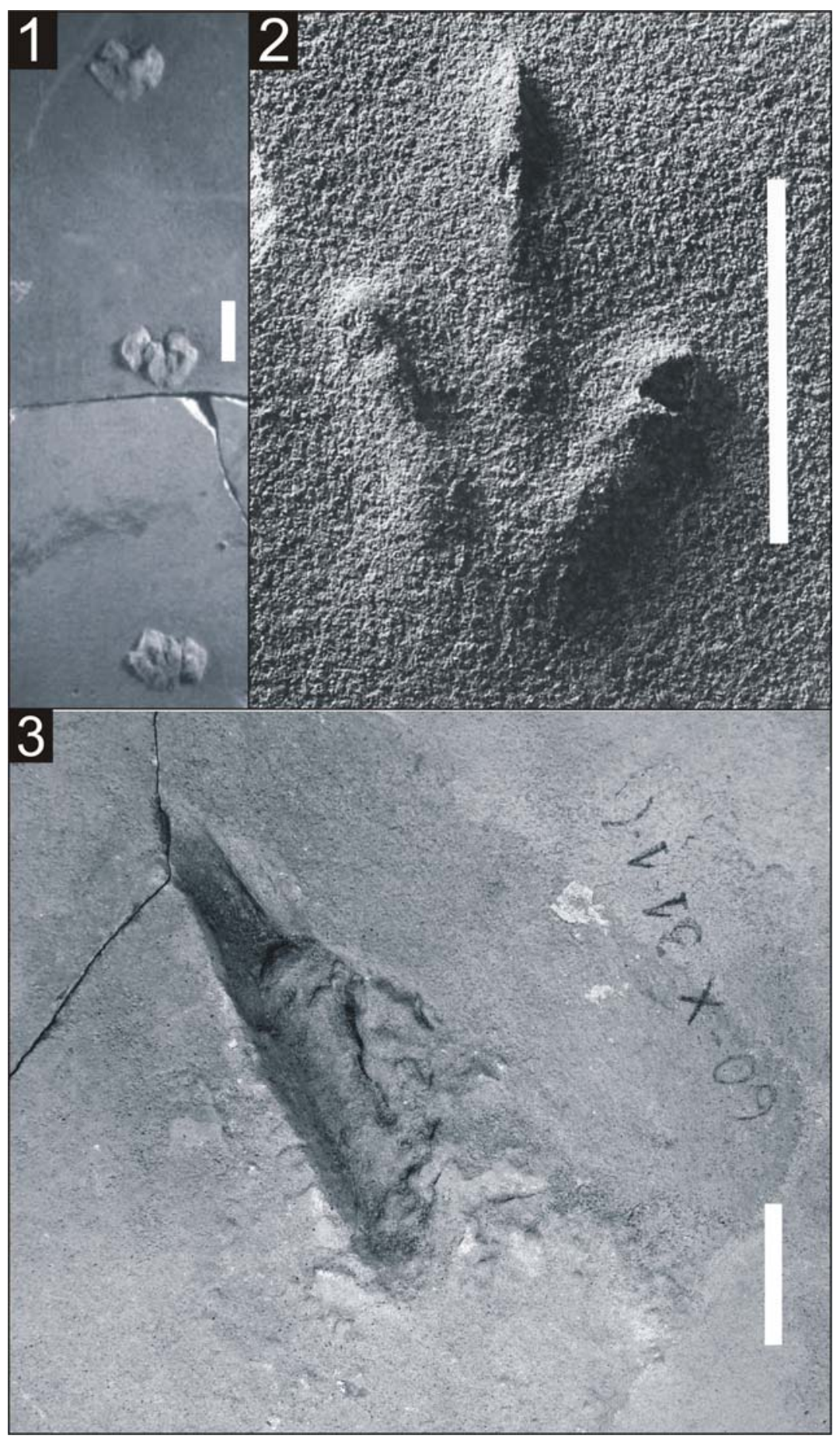

FIGURE 16. Ichnotaxa. 1. Delatorrichnus goyenechei, holotype (MLP 60-X-31-6) (adapted from De Valais, 2011$).$ Wildeichnus navesi, paratype (MLP 60-X-31-11). Sarmientichnus scagliai, holotype (MLP 60-X-31-1A). Scale bar equals $30 \mathrm{~mm}$.

Ichnogenus WILDEICHNUS Casamiquela, 1964

Type ichnospecies. Wildeichnus navesi Casamiquela, 1964

Holotype. MLP 60-X-31-5, isolated left pes print.
Paratypes. MLP 60-X-31-7B, MLP 60-X-31-9, MLP 60-X-31-11 (Figure 16.2).

Referred specimens. MLP 65-XI-12-1, MLP 65$\mathrm{XI}-12-1 / 2$.

Locality and age. Laguna Manantiales ranch, Santa Cruz Province. La Matilde Formation ("Matil- 
dense" sensu Casamiquela, 1964), upper Middle Jurassic-lower Upper Jurassic (Riccardi and Damborenea, 1993; de Valais, 2011 and references therein).

Comments. The holotypic material couldn't be found in the DVP collections. The morphology of the pes is consistent with theropod affinities.

\section{Ichnogenus SARMIENTICHNUS Casamiquela, 1964}

Type ichnospecies. Sarmientichnus scagliai Casamiquela, 1964

Holotype. MLP $60-X-31-1 A$, impression of an isolated right foot (Figure 16.3).

Paratypes. MLP 60-X-31-1B, trackway composed by four tracks, MLP 60-X-31-2A, MLP 60-X-31-2B, natural cast of MLP $60-X-31-1 B$.

Locality and age. Laguna Manantiales, Santa Cruz Province La Matilde Formation ("Matildense" sensu Casamiquela, 1964), upper Middle Jurassiclower Upper Jurassic (Riccardi and Damborenea, 1993; de Valais, 2011 and referencies therein).

Comments. There is a wide consensus in attributing this ichnotaxon to Theropoda (Casamiquela, 1964; Coria and Paulina Carabajal, 2004; de Valais, 2011).

\section{ACKNOWLEDGMENTS}

We would like to thank Z. Gasparini and E.P. Tonni (MLP) for their constant and inexhaustible support during this project. Special thanks to J. Wilson (University of Michigan), who encouraged and supported one of the authors (AO) to perform the project. I. Cerda (Río Negro University) is thanked for provided unpublished information of the indeterminate titanosaurian from Antarctica. J. McIntosh is thanked for provided detail information about his visit to Argentina during 1973. L. Salgado (Río Negro University) and J. Wilson provided useful comments on the manuscript. S. De Valais (Río Negro University) kindly provided photos of some ichnotaxa. We appreciate the recommendations of reviewers J.L. Carballido (Museo Egidio Feruglio), and I.A. Cerda, and Editors J. Louys, H. Mallison, and J. Rumford. We also would like to thank $L$. Acosta, J. Posik, and J. Moly (MLP) for their valuable help and advices in the restoration of the holotype of Argyrosaurus superbus. Special thanks to L. Hernández (Hidroar S.A.) who provided the logistics and for his welding skills during the construction of Argyrosaurus' showcase. This project was accomplished through a grant provided by The Jurassic Foundation to AO.

\section{REFERENCES}

Acosta Hospitaleche, C., Tambussi, C.P., and Reguero, M.A. 2001. Catálogo de los tipos de aves fósiles del Museo de La Plata. Serie Técnica y Didáctica del Museo de La Plata, 41:1-28.

Allain, R. and Aquesbi, N. 2008. Anatomy and phylogenetic relationships of Tazoudasaurus naimi (Dinosauria, Sauropoda) from the Early Jurassic of Morocco. Geodiversitas, 30:345-424.

Bakker, R.T. 1986. The Dinosaur Heresies. William Morrow, New York.

Benton, M.J. 2004. Origin and relationships of Dinosauria, p. 7-19. In Weishampel, D.B., Dodson, P., and Osmólska, H. (eds.), The Dinosauria, 2nd edition. University of California Press, Berkeley.

Berta, A. and Marshall, I.G. 1978. South American Carnivora, p. 1-48. In Westphal, F. (ed.), Fossilium catalogus, I: Animalia. The Hague, Boston/London.

Bonaparte, J.F. 1986. Les dinosaures (Carnosaures, Allosauridés, Sauropodes, Cétiosauridés) du Jurassique moyen de Cerro Cóndor (Chubut, Argentina). Annales de Paléontologie, 72:325-386.

Bonaparte, J.F. 1996. Dinosaurios de América del Sur. Museo Argentino de Ciencias Naturales "Bernardino Rivadavia," Buenos Aires.

Bonaparte, J.F. and Coria, R.A. 1993. Un nuevo y gigantesco sauropodo titanosaurio de la Formación Rio Limay (Albiano-Cenomaniano) de la Provincia del Neuquén, Argentina. Ameghiniana 30:271-282.

Bonaparte, J.F. and Gasparini, Z.B. 1979. Los saurópodos de los grupos Neuquén y Chubut, y sus relaciones cronológicas. Actas $V$ Congreso Geológico Argentino, Neuquén Vol. 2:393-406.

Bond, M. 1986. Los carnívoros terrestres fósiles de la Argentina: resumen de su historia. Actas IV Congreso de Paleontología y Bioestratigrafía, 12:162171.

Bridge, J.S., Jalfin, G.A., and Georgieff, S.M. 2000. Geometry, lithofacies, and spatial distribution of Cretaceous fluvial sandstone bodies, San Jorge Basin, Argentina: outcrop analog for the hydrocarbon-bearing Chubut Group. Journal of Sedimentary Research, 70:341-359.

Butler, R.J., Upchurch, P., and Norman, D.B. 2008. The phylogeny of the ornithischian dinosaurs. Journal of Systematic Palaeontology, 6:1-40.

Cabrera, A. 1926. Cetáceos fósiles del Museo de La Plata. Revista del Museo de La Plata, 29:363-411.

Cabrera, A. 1927. Datos para el conocimiento de los dasiuroideos fósiles argentinos. Revista del Museo de La Plata, 30:271-315.

Cabrera, A. 1929. Una revisión de los mastodontes argentinos. Revista del Museo de La Plata, 32:62144.

Cabrera, A. 1947. Un saurópodo nuevo del Jurásico de Patagonia. Notas del Museo de La Plata 12 Paleontología, 95:1-17. 
Carballido, J.L. and Pol, D. 2010. The dentition of Amygdalodon patagonicus (Dinosauria: Sauropoda) and the dental evolution in basal sauropods. Comptes Rendus Palevol, 9:83-93.

Carballido, J.L., Rauhut, O.W.M., Pol, D., and Salgado, L. 2011. Osteology and phylogenetic relationships of Tehuelchesaurus benitezii (Dinosauria, Sauropoda) from the Upper Jurassic of Patagonia. Zoological Journal of the Linnean Society, 163:605-662.

Casal, G., Martínez, R., Luna, M., Sciutto, J.C., and Lamanna, M. 2007. Aeolosaurus colhuehuapensis sp. nov. (Sauropoda, Titanosauria) de la Formación Bajo Barreal, Cretácico Superior de Argentina. Revista Brasileira de Paleontologia, 10:53-62.

Casamiquela, R.M. 1963. Consideraciones acerca de Amygdalodon Cabrera (Sauropoda, Cetiosauridae) del Jurásico medio de la Patagonia. Ameghiniana, 3:79-95.

Casamiquela, R. M. 1964. Estudios icnológicos. Problemas y métodos de la icnología con aplicación al estudio de pisadas mesozoicas (Reptilia, Mammalia) de la Patagonia. Colegio Industrial Pío IX, Buenos Aires.

Casamiquela, R.M. 1966. Algunas consideraciones teóricas sobre los andares de los dinosaurios saurisquios. Implicaciones filogenéticas. Ameghiniana, 4:373-385.

Casamiquela, R.M. 1980. La presencia del género Plateosaurus (Prosauropoda) en el Triásico superior de la Formación El Tranquilo, Patagonia. Actas I/ Congreso Argentino de Paleontología y Bioestratigrafía. I Congreso Latinoamericano de Paleontología, 1:143158.

Case, J.A., Martin, J.E., Chaney, D.S., Reguero, M., Marenssi, S.A., and Santillana, S. 2000. The first duck-billed dinosaur (Family Hadrosauridae) from Antarctica. Journal of Vertebrate Paleontology, 20:612-614.

Cerda, I.A., Paulina Carabajal, A., Salgado, L., Coria, R.A., Moly, J.J., and Reguero, M. 2011. The first record of sauropod dinosaurs from Antarctica. Journal of Vertebrate Paleontology, 31 (suppl.), p. 86A.

Cope, E.D. 1869. Synopsis of the extinct Batrachia, Reptilia, and Aves of North America. Transactions of the American Philosophical Society, 14:1-252.

Coria, R.A. 2007. Nonavian theropods, p. 229-256. In Gasparini, Z.N., Salgado, L., and Coria, R.A. (eds.), Patagonian Mesozoic Reptiles. Indiana University Press, Bloomington and Indianapolis.

Coria, R.A. and Paulina Carabajal, A. 2004. Nuevas huellas de Theropoda (Dinosauria: Saurischia) del Jurásico de Patagonia, Argentina. Ameghiniana, 41:393-398.

D'Emic, M.D. 2012. The early evolution of titanosauriform sauropod dinosaurs. Zoological Journal of the Linnean Society, 166:-671.
D'Emic, M.D. and Wilson, J.A. 2011. New remains attributable to the holotype of the sauropod dinosaur Neuquensaurus australis, with implications for saltasaurine systematics. Acta Palaeontologica Polonica, 56:61-73.

de Valais, S. 2011. Revision of dinosaur ichnotaxa from the La Matilde Formation (Middle Jurassic), Santa Cruz Province, Argentina. Ameghiniana, 48:28-42.

Ezcurra, M.D. 2010. A new early dinosaur (Saurischia: Sauropodomorpha) from the Late Triassic of Argentina: a reassessment of dinosaur origin and phylogeny. Journal of Systematic Palaeontology, 8:371425.

Galton, P.M. 1990. Basal Sauropodomorpha-Prosauropoda, p. 320-344. In Weishampel, D.B., Dodson, P., and Osmólska, H. (eds.), The Dinosauria. University of California Press, Berkeley.

Galton, P.M. and Upchurch, P. 2004. Prosauropoda, p. 232-258. In Weishampel, D.B., Dodson, P., and Osmólska, H. (eds.), The Dinosauria, 2nd edition. University of California Press, Berkeley.

Garrido, A.C. 2010. Estratigrafía del Grupo Neuquén, Cretácico Superior de la Cuenca Neuquina (Argentina): nueva propuesta de ordenamiento litoestratigráfico. Revista del Museo Argentino de Ciencias Naturales, n. s., 12:121-177.

Gasparini, Z., Olivero, E., Scasso, R., and Rinaldi, C. 1987. Un ankilosaurio (Reptilia, Ornithischia) Campaniano en el continente antártico. Anais do X Congresso Brasileiro de Paleontologia, Río de Janeiro, 131-141.

Gauthier, J.A. 1986. Saurischian monophyly and the origin of birds, p. 1-55. In Padian, K. (ed.), The origin of birds and the evolution of flight. Memoirs of the California Academy of Sciences, 8:1-55.

Hammer, W.R. and Hickerson, W.J. 1994. A crested theropod dinosaur from Antarctica. Science, 264:828-830.

Holtz, T.R. Jr., Molnar, R.E., and Currie, P.J. 2004. Basal Tetanurae, p. 71-110. In Weishampel, D.B., Dodson, P., and Osmólska, H. (eds.), The Dinosauria, 2nd edition. University of California Press, Berkeley.

Ibiricu, L.M., Martínez, R.D., Lamanna, M.C., Casal, G.A., Luna, M., Harris, J.D., and Lacovara K.J. 2010. A medium-sized ornithopod (Dinosauria: Ornithischia) from the Upper Cretaceous Bajo Barreal Formation of Lago Colhué Huapi, southern Chubut Province, Argentina. Annals of Carnegie Museum, 79:39-50.

Keidel, J. 1917. Über das patagonische Tafelland, das patagonische Geröll und ihre Beziehungen zu den geologischen Erscheinungen im argentinischem Andengebiet und Litoral. Zeitschrift des Deutschen Wissensschaftlichen Vereins, 3:311-333.

Lambe, L.M. 1918. On the genus Trachodon of Leidy. Ottawa Naturalist, 31:135-139 
Leanza, H.A. 1999. The Jurassic and Cretaceous terrestrial beds from Southern Neuquén Basin, Argentina. Field Guide. Instituto Superior de Correlación Geológica. INSUGEO. Serie Miscelánea, 4:1-30.

Leanza, H.A. and Hugo, C.A. 2001. Cretaceous red beds from southern Neuquén Basin (Argentina): age, distribution and stratigraphic discontinuities. VII International Symposium on Mesozoic Terrestrial Ecosystems. Asociación Paleontológica Argentina, Publicación Especial, 7:117-122.

Leanza, H.A., Apesteguía, S., Novas, F.E., and de la Fuente, M.S. 2004. Cretaceous terrestrial beds from the Neuquén Basin (Argentina) and their tetrapod assemblages. Cretaceous Research, 25:61-87.

Lydekker, R. 1877. Notices of new and other Vertebrata from Indian Tertiary and Secondary rocks. Records of the Geological Survey of India, 10:30-43.

Lydekker, R. 1888. Catalogue of the Fossil Reptilia and Amphibia in the British Museum (Natural History), Part 1. British Museum of Natural History, London.

Lydekker, R. 1893. The dinosaurs of Patagonia. Anales Museo de La Plata, 2:1-14.

Macellari, C.E. 1988. Stratigraphy, sedimentology, and paleoecology of Upper Cretaceous/Paleocene shelfdeltaic sediments of Seymour Island. In Feldmann, R.M. and Woodburne, M.O. (eds.), Geology and Paleontology of Seymour Island, Antarctic Peninsula. Geological Society of America Memoir, 169:25-53.

Maleev, E.A. 1974. Gigantic carnosaurs of the family Tyrannosauridae. Sovmestnaja Sovetsko-Mongolskaja Paleontologisheskaja Ekspedicija Trudy 1:132191. (in Russian)

Mannion, P.D. and Otero, A. 2012. A reappraisal of the Late Cretaceous Argentinean sauropod dinosaur Argyrosaurus superbus, with a description of a new titanosaur genus. Journal of Vertebrate Paleontology, 32:614-638.

Marsh, O.C. 1878. Principal characters of American Jurassic dinosaurs. Part I. American Journal of Science (Series 3), 16:411-416.

Marsh, O.C. 1881. Principal characters of American Jurassic dinosaurs. Part V. American Journal of Science (Series 3), 21:417-423.

Marsh, O.C. 1884. Principal characters of American Jurassic dinosaurs. Part VIII. The order Theropoda. American Journal of Science, 27:329-340.

Marsh, O.C. 1890. Additional characters of the Ceratopsidae with notice of new Cretaceous dinosaurs. American Journal of Science (Series 3), 39:418-426.

Martinelli, A. and Forasiepi, A. 2004. Late Cretaceous vertebrates from Bajo de Santa Rosa (Allen Formation), Río Negro province, Argentina, with the description of a new sauropod dinosaur (Titanosauridae). Revista Museo Argentino de Ciencias Naturales, n. s., 6:257-305.

McIntosh, J.S. 1990. Sauropoda, p. 345-401. In Weishampel, D.B., Dodson, P., and Osmólska, H. (eds.), The Dinosauria. University of California Press, Berkeley.
Mercerat, A. 1891. Caracteres diagnósticos de algunas especies de Creodonta conservados en el Museo de La Plata. Revista del Museo de La Plata, 2:51-56.

Mercerat, A. 1895. Amphinasua brevirostris Moreno y Mercerat. Revista del Museo de La Plata, 6:253-264.

Mones, A. 1986. Paleovertebrata sudamericana. Catálogo sistemático de los vertebrados fósiles de América del Sur. Parte I. Lista prelimiar y bibliografía. Courier Forschungsinstitut Seckenberg, 82:1-625.

Nesbitt, S.J. 2011. The Early evolution of archosaurs: relationships and the origin of major clades. Bulletin of the American Museum of Natural History, 352:1292. doi:10.1206/352.1.

Nopcsa, F. 1915. Die Dinosaurier der Siebenbürgischen Landesteile Ungarns. Mitteilungen aus den Jahrbuch der Königlich Ungarnischen Geologischen Reichsanstalt, 23:1-26.

Novas, F.E. 1996. Dinosaur monophyly. Journal of Vertebrate Paleontology, 16:723-741.

Olivero, E. 1992. Asociaciones de amonites de la Formación Santa Marta (Cretácico tardío), Isla James Ross, p. 45-75. In Rinaldi, C. (ed.), Geología de la Isla James Ross. Instituto Antártico Argentino, Buenos Aires.

Olivero, E., Gasparini, Z., Rinaldi, C., and Scasso, R. 1991. First record of dinosaurs in Antarctica (Upper Cretaceous, James Ross Island): paleogeographical implications, p. 617-622. In Thompson, R.A.N., Crame, J.A., and Thomson, J.W. (eds.), Geological Evolution of Antarctica. Cambridge University Press, Cambridge.

Olivero, E.B., Ponce, J.J., Marsicano, C.A., and Martinioni, D.R. 2007. Depositional settings of the basal López de Bertodano Formation, Maastrichtian, Antarctica. Revista de la Asociación Geológica Argentina, 62: 521-529.

Osborn, H.F. 1923. Two lower Cretaceous dinosaurs from Mongolia. American Museum Novitates, 95:110.

Otero, A. 2010. The appendicular skeleton of Neuquensaurus, a Late Cretaceous saltasaurine sauropod from Patagonia, Argentina. Acta Palaeontologica Polonica, 55:299-326.

Owen, R. 1842. Report on British fossil reptiles, part II. Report for the British Association for the Advancement of Science, Plymouth, 60-294.

Paul, G.S. 1988. Predatory dinosaurs of the world. Simon and Schuster, New York.

Pol, D., Garrido, A., and Cerda, I.A. 2011. A New sauropodomorph dinosaur from the Early Jurassic of Patagonia and the origin and evolution of the sauropod-type sacrum. PLOS ONE, 6:e14572. doi:10.1371/journal.pone.0014572.

Powell, J.E. 1980. Sobre la presencia de una armadura dérmica en algunos dinosaurios titanosauridos. Acta Geologica Lilloana, 15:41-47.

Powell, J.E. 1986. Revisión de los titanosáuridos de América del Sur. Ph,D, Thesis, Universidad Nacional de Tucumán, Argentina. 
Powell, J.E. 1992. Osteología de Saltasaurus loricatus (Sauropoda-Titanosauridae) del Cretácico Superior del Noroeste Argentino, p. 165-230. In Sanz, J.L. and Buscalioni, A.D. (eds.), Los Dinosaurios y su entorno biótico. Actas Segundo Curso de Paleontología en Cuencas-Instituto 'Juan De Valdes'.

Powell, J.E. 2003. Revision of South American Titanosaurid dinosaur: palaeobiological, palaeobiogeographical and phylogenetic aspects. Records of the Queen Victoria Museum, 111:1-173.

Prevosti, F.J. and Reguero, M.A. 2000. Catálogo de tipos de vertebrados fósiles del Museo de La Plata. I. Carnivora. Serie Técnica y Didáctica del Museo de La Plata, 28:1-12.

Prieto-Márquez, A. and Salinas, G.C. 2010. A re-evaluation of Secernosaurus koerneri and Kritosaurus australis (Dinosauria, Hadrosauridae) from the Late Cretaceous of Argentina. Journal of Vertebrate Paleontology, 30:813-837.

Prosepio, C.A. 1987. Descripción geológica de la hoja $44 \mathrm{e}$, Valle General Racedo. Boletín de la Dirección Nacional de Minería y Geología, 210:1-102.

Rauhut, O.W. 2003. Revision of Amygdalodon patagonicus Cabrera, 1947 (Dinosauria Sauropoda). Fossil Record, 6:173-181.

Rauhut, O.W.M. 2004. Provenance and anatomy of Genyodectes serus, a large-toothed ceratosaur (Dinosauria: Theropoda) from Patagonia. Journal of Vertebrate Paleontology, 24:894-902.

Riccardi, A.C. and Damborenea, S.E. 1993. Léxico Estratigráfico de la Argentina, Vol. 9, Jurásico. Asociación Geológica Argentina. Buenos Aires.

Rich, T.H., Vickers-Rich, P., Fernández, M., and Santillana, S. 1999. A probable hadrosaur from Seymour Island, Antarctic Peninsula, p. 219-222. In Tomida, Y., Rich, T.H., and Vickers-Rich, P. (eds.), Proceedings of the Second Gondwanan Dinosaur Symposium. National Science Museum Monographs No. 15, Tokyo.

Roth, S. 1898. Catálogo de los mamíferos fósiles conservados en el Museo de La Plata. Grupo Ungulata. Orden Toxodontia. Revista del Museo de La Plata, 8:33-160.

Salgado, L. 2007. Patagonia and the study of its mesozoic reptiles: a brief history, p. 1-28. In Gasparini, Z.N., Salgado, L., and Coria, R.A. (eds.), Patagonian Mesozoic Reptiles, Indiana University Press, Bloomington and Indianapolis.

Salgado, L. and Azpilicueta, C. 2000. Un nuevo saltasaurino (Sauropoda, Titanosauridae) de la provincia de Río Negro (Formación Allen, Cretácico Superior), Patagonia, Argentina, Ameghiniana, 37:259-264.

Salgado, L. and Bonaparte, J.F. 2007. Sauropodomorpha, p. 188-228. In Gasparini, Z., Salgado, L. and Coria, R.A. (eds.), Patagonian Mesozoic Reptiles. Indiana University Press, Bloomington and Indianapolis.
Salgado, L. and Gasparini, Z. 2006. Reappraisal of an ankylosaurian dinosaur from the Upper Cretaceous of James Ross Island (Antarctica). Geodiversitas, 28: 119-135.

Salgado, L., Coria, R.A., and Calvo, J.O. 1997. Evolution of titanosaurid sauropod I: phylogenetic analysis based on the postcranial evidence. Ameghiniana, 34:3-32.

Sanz, J.L., Powell, J.E., Le Loeuff, J., Martínez, R., and Pereda-Suberiola, X. 1999. Sauropod remains from the Upper Cretaceous of Laño (northcentral Spain), titanosaur phylogenetic relationships. Estudios del Museo de Ciencias Naturales de Nava, 14:235-255.

Seeley, H.G. 1888. On the classification of the fossil animals commonly named Dinosauria. Proceedings of the Royal Society of London, 43:165-171.

Sereno, P.C. 1986. Phylogeny of the bird-hipped dinosaurs (Order Ornithischia). National Geographic Research, 2:234-256.

Sereno, P.C. 1989. Prosauropod monophyly and basal sauropodomorph phylogeny. Journal of Vertebrate Paleontology, 9:38A.

Sereno, P.C. 1997. The origin and evolution of dinosaurs. Annual Review of Earth and Planetary Science, 25:435-489.

Sereno, P.C. 1998. A rationale for phylogenetic definitions, with application to the higher-level taxonomy of Dinosauria. Neues Jahrbuch für Geologie und Paläontologie - Abhandlungen, 210, 41-83.

Sereno, P.C. 1999. A rationale for dinosaurian taxonomy. Journal of Vertebrate Paleontology, 19:788-790.

Smith, N.D. and Pol, D. 2007. Anatomy of a basal sauropodomorph dinosaur from the Early Jurassic Hanson Formation of Antarctica. Acta Palaeontologica Polonica, 52:657-674.

Thompson, R.S., Parish, J.C., Maidment, S.C.R., and Barrett, P.M. 2012. Phylogeny of the ankylosaurian dinosaurs (Ornithischia: Thyreophora). Journal of Systematic Palaeontology, 10:301-312.

Tykosky, R.S. and Rowe, T. 2004. Ceratosauria, p. 4770. In Weishampel, D.B., Dodson, P., and Osmólska, H. (eds.), The Dinosauria, 2nd edition University of California Press, Berkeley.

Upchurch, P., Barrett, P.M., and Dodson, P. 2004. Sauropoda, p. 259-322. In Weishampel, D.B., Dodson, P., and Osmólska, H. (eds.), The Dinosauria, 2nd edition. University of California Press, Berkeley.

Vickaryous, M.K., Maryánska, T., and Weishampel, D.B. 2004. Ankylosauria, p. 363-392. In Weishampel, D.B., Dodson, P., and Osmólska, H. (eds.), The Dinosauria, 2nd edition. University of California Press, Berkeley.

von Huene, F. 1914. Das natürliche System der Saurischia. Centralblatt für Mineralogie, Geologie und Paläontologie 1914:154-158

von Huene, F. 1929. Los Saurisquios y Ornitisquios del Cretáceo Argentino. Anales Museo de La Plata, 3:1194. 
von Huene, F. 1932. Die fossil Reptil-Ordnung Saurischia, ihre Entwicklung und Geschichte. Monographien zur Geologie und Palaeontologie, 4:1-361.

Wichmann, R. 1916. Las capas con dinosaurios de la costa sur del Río Negro, frente a General Roca. Revista de la Sociedad Argentina de Ciencias Naturales, vol. 2:258-62.

Wilson, J.A. 2002. Sauropod dinosaur phylogeny: critique and cladistic analysis. Zoological Journal of the Linnean Society, 136: 217-276.

Wilson, J.A. and Sereno, P.C. 1998. Early evolution and higher-level phylogeny of sauropod dinosaurs. Society of Vertebrate Paleontology Memoir, 5:1-68.

Wilson, J.A. and Upchurch, P. 2003. A revision of Titanosaurus Lydekker (Dinosauria-Sauropoda), the first dinosaur genus with a 'Gondwanan' distribution. Journal of Systematc Palaeontology, 1:125-160.
Woodward, A.S. 1901. On some extinct reptiles from Patagonia, of the genera Miolania, Dinilysia, and Genyodectes. Proceedings of the Zoological Society of London, 1901:169-184.

Yates, A.M. 2003. The species taxonomy of the sauropodomorph dinosaurs from the Löwenstein Formation (Norian, Late Triassic) of Germany. Palaeontology, 46:317-337.

Yates, A.M. 2004. Anchisaurus polyzelus (Hitchcock): the smallest known sauropod dinosaur and the evolution of gigantism among sauropodomorph dinosaurs. Postilla, 230:1-58.

Yates, A.M. 2007a. The first complete skull of the Triassic dinosaur Melanorosaurus Haughton (Sauropodomorpha: Anchisauria). Special Papers in Palaeontology, 77:9-55.

Yates, A.M. 2007b. Solving a dinosaurian puzzle: the identity of Aliwalia rex Galton. Historical Biology, 19:93-123. 